\title{
Aspergillus niger: A Hundred Years of Contribution to the Natural Products Chemistry
}

\author{
Mary Anne S. Lima, ${ }^{\circledR *, a}$ Maria da Conceição F. de Oliveira, ${ }^{a}$ Antônia T. Á. Pimenta ${ }^{a}$ \\ and Paula K. S. Uchôa ${ }^{b}$ \\ ${ }^{a}$ Departamento de Química Orgânica e Inorgânica, Universidade Federal do Ceará, \\ 60021-940 Fortaleza-CE, Brazil \\ ${ }^{b}$ Instituto Federal de Educação, Ciência e Tecnologia do Ceará, Campus Iguatu, \\ 63500-000 Iguatu-CE, Brazil
}

\begin{abstract}
Aspergillus niger is a phytopathogenic fungus responsible for the plant disease called "black mold", and it is considered the most versatile microorganism for producing acids, proteins, and enzymes of industrial value, besides a variety of compounds of pharmacological interest. This review presents a century of contribution of A. niger in the natural products chemistry under two different perspectives: $(i)$ an overview of the structural diversity of secondary metabolites produced by $A$. niger from different habitats and their biological activities; (ii) a general discussion of the enzymatic potential of $A$. niger on the selective biotransformation of terpenes, highlighting the most uncommon microbial transformations.
\end{abstract}

Keywords: Aspergillus niger, secondary metabolites, biological activities, biotransformation, terpenes

\section{Introduction}

Aspergillus niger is a member of a group of species named Aspergillus section Nigri, formerly known as A. niger group. ${ }^{1}$ This fungus causes the "black mold" disease and it is the most common contaminant of stored food, being responsible for postharvest decay of fresh fruits, grains, and crops worldwide. ${ }^{2}$

The productive metabolism of $A$. niger acquired a great economic importance when James Currie ${ }^{3}$ (1917) published a study describing the ability of the fungus to biosynthesize high amounts of citric acid by culturing it in sugar solutions at low $\mathrm{pH}$. This remarkable discovery showed the direct influence of the ambient and nutritional factors in the yield of the citric acid production and was the basis for the birth of the biotechnology industry in 1919 by Pfizer. ${ }^{4}$

The biotechnological revolution after Currie's discovery constituted the major focus of the investigation of $A$. niger, that rapidly grew in the next 40 years. The initial studies were predominantly related to the biochemical mechanism of accumulation of citric acid, the impact of micro and macronutrients in the cultivation media and the optimization of the growth parameters. These investigations generated

*e-mail: mary@dqoi.ufc.br an efficient high yielding bioprocess, and actually, citric acid is one of the most valuable commercial chemical products due to its widespread use in food, cosmetics, and pharmaceutical formulations. ${ }^{4-8}$

The modernization of the analytical techniques in the following decades also revealed this microorganism to be a prolific secretor of a diverse range of useful proteins. A large number of unique proteins involved in certain mechanisms do not occur in other filamentous fungi, proving that this species is quite versatile at the level of cellular production. ${ }^{9}$ These discoveries significantly contributed to the fundamental understanding of enzyme function and to the production of numerous extracellular enzymes, such as $\alpha$-amylase, oxidase, catalase, dehydrogenase, hydrolase, cellulase, pectinase, among others. ${ }^{10-15}$

The advent of molecular biology and the development of the transcriptomic and metabolomic techniques revealed scores of hitherto unknown information and allowed the elucidation of the full genome sequence of some A. niger strains. ${ }^{9,10,16,17}$ These events opened a new perspective for both chemical studies and biotechnological applications and facilitated a great insight into the secondary metabolites genes for the understanding of the growth, differentiation, physiology, and mainly the biosynthesis of natural products. 
Therefore, all these scientific achievements over a century of the investigation resulted in a range of new processes and compounds and contributed to the great interest about the chemical versatility and the pharmacological potential of secondary metabolites from A. niger. Investigations focused on the screening of bioactive compounds using strains from different habitats, modifications on the fermentation routes, ${ }^{8}$ genome editing, ${ }^{18,19}$ epigenetic modulation, ${ }^{20,21}$ and microbial biotransformation, ${ }^{22-24}$ and revealed A. niger as a powerful tool for the production of diverse and structurally complex compounds endowed with an ingenious structure for the experimental drug research area.

In order to celebrate the centenary contribution of A. niger to the natural products chemistry, in this review we present an overview of the origin of the chemically investigated strains and the structural diversity of secondary metabolites produced so far by this fungus, besides the biological activities of the evaluated compounds in the literature. Additionally, the potential of A. niger on the selective biotransformation of terpenes is summarized, and examples of the most uncommon microbial transformations are highlighted.

\section{Characteristics and Occurrence of A. niger}

Species from Aspergillus genus section Nigri present a thin stalk with a round black conidial head made up of spores of a characteristic shape, which bud from the organism's body as part of asexual reproduction. Its name is derived from this appearance since it resembles the holy water sprinkler called aspergillum, used by priests during the Asperges ceremony. ${ }^{25}$

A. niger is considered a cosmopolitan asexual saprophyte, occurring in almost all aerobic environments. It is thermotolerant, being able to thrive in freezing conditions and very hot weather, and to multiply within a temperature range of between 6 and $47{ }^{\circ} \mathrm{C}$. The optimal $\mathrm{pH}$ for this fungus growing is 6 , although it tolerates wide $\mathrm{pH}$ range (from 1.5 to 9.8). In addition, the most favorable water activity and relative humidity to observe the growth of this species is 0.97 and $96-98 \%$, respectively. ${ }^{26}$ The black spores of A. niger apparently provide protection from sunlight and UV irradiation, leading to a competitive advantage over other microorganisms in their habitats. These abilities besides the profuse production of conidiospores spread through air, ensure its more frequent occurrence in warm and humid habitats. ${ }^{27}$

According to our literature survey, the chemical investigations of A. niger for secondary metabolites production were accomplished with strains from different sources/habitats and the percentage distribution is shown at Figure 1.

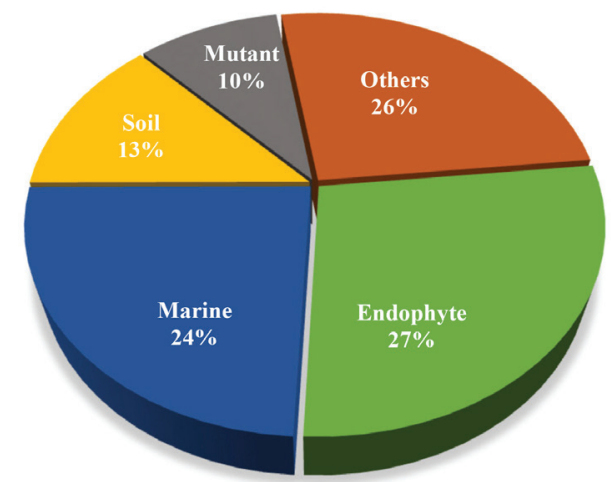

Figure 1. Percentage distribution of sources/habitats reported to A. niger strains investigated for secondary metabolites production.

Endophyte strains of $A$. niger were the most predominant sources used in chemical studies, which was closely followed by strains associated to marine habitats and others. This latter comprises those strains coming from either fungi collections or without information of their source/ habitat. Additionally, it was possible to note a significant contribution of chemical investigations of strains derived from genetic mutation. It is important to mention that some compounds were produced by strains from different sources/habitats, suggesting that environmental conditions had no influence on this fungus metabolism.

\section{Secondary Metabolites from A. niger Strains}

The literature survey (from 1917 to 2018) revealed 213 secondary metabolites produced by A. niger strains from different sources and corroborated this fungus species as a proficuous source of natural products. Herein, these compounds were classified into 13 different groups based on their structural characteristics (sections 3.1 to 3.12), whose presentation order follows their natural abundance. Additionally, a miscellaneous group (section 3.13) was included which display those minor or structurally unique compounds. Although all chemical structures and their sources were present in all groups, only some representatives and/or bioactive compounds were discussed.

Structures of compounds were displayed in Figures 2-14 where their numbering system was based on that described in the literature. All compounds' names were listed in alphabetical order in Tables 1-13.

\subsection{Naphto- $\gamma$-pyrones}

Naphtho- $\gamma$-pyrones (NGPs) are an important group of 
aromatic polyketides that have been isolated of $A$. niger from a wide variety of habitats (1-40, Figure 2, Table 1) and, among these compounds, bis-naphtho- $\gamma$-pyrones (BNPs) represent the major secondary metabolites produced by Aspergillus species. ${ }^{28-45}$ Based on the diaryl bond connection, BNPs are commonly found in this genus as asperpyrone- and nigerone-types being, therefore, taxonomically significant.
The asperpyrone-type BNPs have large natural abundance in A. niger and display C-10-C-7', C-10-C-9', C-6-C-7' or C-6-C-9' linkages between the monomeric unities. According to these linkage patterns, they are named as aurasperones, isoaurasperones, asperpyrones, fonsecinones, and nigerasperones. ${ }^{45}$ Aurasperonas A-H (6-13, Figure 2) are 10,7'-bisnaphtho- $\gamma$-pyrones that have been isolated from different strains and habitats,



$6 \mathrm{R}^{1}=\mathrm{R}^{2}=\mathrm{R}^{5}=\mathrm{R}^{7}=\mathrm{H}, \mathrm{R}^{3}=\mathrm{R}^{4}=\mathrm{R}^{6}=\mathrm{R}^{8}=\mathrm{R}^{9}=\mathrm{CH}_{3}$

$9 \mathrm{R}^{1}=\mathrm{R}^{2}=\mathrm{R}^{5}=\mathrm{R}^{7}=\mathrm{R}^{8}=\mathrm{H}, \mathrm{R}^{3}=\mathrm{R}^{4}=\mathrm{R}^{6}=\mathrm{R}^{9}=\mathrm{CH}_{3}$

$12 \mathrm{R}^{1}=\mathrm{R}^{4}=\mathrm{R}^{7}=\mathrm{H}, \mathrm{R}^{2}=\mathrm{R}^{5}=\mathrm{OH}, \mathrm{R}^{3}=\mathrm{R}^{6}=\mathrm{R}^{8}=\mathrm{R}^{9}=\mathrm{CH}_{3}$

$13 \mathrm{R}^{1}=\mathrm{R}^{2}=\mathrm{R}^{5}=\mathrm{R}^{7}=\mathrm{H}, \mathrm{R}^{3}=\mathrm{R}^{4}=\mathrm{R}^{8}=\mathrm{R}^{9}=\mathrm{CH}_{3}, \mathrm{R}^{6}=-\mathrm{CH}_{2} \mathrm{CH}(\mathrm{OH}) \mathrm{CH}_{3}$

$16 \mathrm{R}^{1}=\mathrm{R}^{2}=\mathrm{R}^{4}=\mathrm{R}^{5}=\mathrm{R}^{7}=\mathrm{H}, \mathrm{R}^{3}=\mathrm{R}^{6}=\mathrm{R}^{8}=\mathrm{R}^{9}=\mathrm{CH}_{3}$

$26 \mathrm{R}^{2}=\mathrm{R}^{3}=\mathrm{R}^{5}=\mathrm{R}^{8}=\mathrm{H}, \mathrm{R}^{1}=\mathrm{R}^{4}=\mathrm{R}^{6}=\mathrm{R}^{7}=\mathrm{R}^{9}=\mathrm{CH}_{3}$

$27 \mathrm{R}^{1}=\mathrm{R}^{2}=\mathrm{R}^{5}=\mathrm{R}^{7}=\mathrm{H}, \mathrm{R}^{3}=\mathrm{R}^{4}=\mathrm{R}^{6}=\mathrm{R}^{8}=\mathrm{R}^{9}=\mathrm{CH}_{3}$<smiles>COc1cc(OC)c2c(O)c3c(=O)cc(Cl)oc3c(-c3c(O)cc4cc5c(c(O)c4c3OC)C(=O)CC(C)(O)O5)c2c1</smiles>

28<smiles>[R20]c1cc2cc3oc(C)cc(=O)c3c(O)c2c(OC)c1-c1c2c(c(O)c3c(OC)cc(OC)cc13)C(=O)CC(C)(O)O2</smiles>

$21 \mathrm{R}=\mathrm{CH}_{3}$

$32 \mathrm{R}=\mathrm{H}$<smiles>COc1cc(OC)c2c(O)c3c(=O)cc(C)oc3c(-c3c(OC)cc4cc5c(c(O)c4c3OC)C(=O)CC(C)(O)O5)c2c1</smiles>

$11 \mathrm{R}=\mathrm{H}$<smiles>[R6]c1cc2cc(O)c3c(=O)cc(C)oc3c2c(OC)c1-c1c2cc(OC)cc(OC)c2c(O)c2c(=O)cc(C)oc12</smiles>

$1 \mathrm{R}=\mathrm{H}$

$20 \mathrm{R}=\mathrm{CH}_{3}$

Figure 2. Chemical structures of naphyto- $\gamma$-pyrones (1-40) produced by A. niger strains. 
<smiles>COc1cc(O)c2c(c1)c(-c1c(O)cc3cc4oc(C)cc(=O)c4c(O)c3c1O)c(O)c1c(=O)cc(C)oc12</smiles>

$3 \mathrm{R}=\mathrm{CH}_{3}$<smiles>COc1cc(O)c2c(-c3c(O)c4c(=O)cc(C)oc4c4c(OC)cc(O)cc34)c(O)c3c(=O)cc(C)oc3c2c1</smiles>

$2 \mathrm{R}=\mathrm{CH}_{3}$<smiles></smiles>

24<smiles></smiles>

31<smiles>[R9]Oc1cc([R9])c2c(O)c3c(=O)cc([R])oc3c([Z7])c2c1</smiles>

$30 \mathrm{R}^{1}=\mathrm{CH}_{2} \mathrm{OH}, \mathrm{R}^{2}=\mathrm{R}^{3}=\mathrm{CH}_{3}, \mathrm{R}^{4}=\mathrm{H}$

$34 \mathrm{R}^{1}=\mathrm{CH}_{3}, \mathrm{R}^{2}=\mathrm{R}^{3}=\mathrm{R}^{4}=\mathrm{H}$

$35 \mathrm{R}^{1}=\mathrm{R}^{2}=\mathrm{R}^{3}=\mathrm{CH}_{3}, \mathrm{R}^{4}=\mathrm{H}$

$36 \mathrm{R}^{1}=\mathrm{R}^{2}=\mathrm{R}^{4}=\mathrm{H}, \mathrm{R}^{3}=\mathrm{CH}_{3}$

$37 \mathrm{R}^{1}=\mathrm{R}^{3}=\mathrm{CH}_{3}, \mathrm{R}^{4}=\mathrm{H}, \mathrm{R}^{2}=-\mathrm{O}$

$38 \mathrm{R}^{1}=\mathrm{R}^{2}=\mathrm{CH}_{3}, \mathrm{R}^{3}=\mathrm{H}, \mathrm{R}^{4}=39 \mathrm{R}^{1}=\mathrm{R}^{2}=\mathrm{CH}_{3}, \mathrm{R}^{3}=\mathrm{R}^{4}=\mathrm{H}_{\mathrm{NH}}$<smiles>[R20]c1cc(OC)c2c(O)c3c(cc2c1)OC(C)(O)CC3=O</smiles>

$19 \mathrm{R}=\mathrm{CH}_{3}$

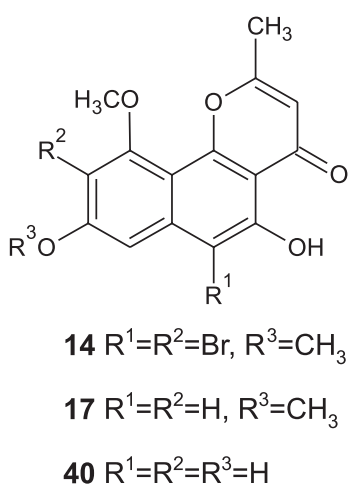<smiles>[R15][R5]=C</smiles><smiles>CCOc1cc2cc(O)cc(O)c2c(O)c1C(C)=O</smiles>

38<smiles></smiles>

25

Figure 2. Chemical structures of naphyto- $\gamma$-pyrones (1-40) produced by A. niger strains (cont.).

and some of them have been shown relevant biological activity. Aurasperone A (6), produced by an endophyte strain from Cynodon dactylon, showed strong inhibitory action on xanthine oxidase (XO), antimicrobial activity against Candida albicans and Trichophyton rubrum, similar to the positive reference ketoconazole. ${ }^{32}$ This compound, biosynthesized by a strain recovered from Japanese soil, also acted on Taq DNA polymerase..$^{28}$ 
Table 1. Naphtho- $\gamma$-pyrones (NPGs, 1-40) produced by A. niger strains

\begin{tabular}{|c|c|c|c|}
\hline Compound & Strain & Source & Reference \\
\hline \multirow{4}{*}{ Asperpyrone A (1) } & JV 33-48 & soil & 28 \\
\hline & SCSIO Jcsw6F30 & marine & 29 \\
\hline & $\mathrm{nr}$ & endophyte & 30 \\
\hline & EN 13 & marine & 31 \\
\hline \multirow{3}{*}{ Asperpyrone B (2) } & IFBE 003 & endophyte & 32 \\
\hline & JV 33-48 & soil & 28 \\
\hline & 2HL M-8 & marine & 33 \\
\hline \multirow{3}{*}{ Asperpyrone C (3) } & JV 33-48 & soil & 28 \\
\hline & 2HL M-8 & marine & 33 \\
\hline & EN 13 & marine & 31 \\
\hline \multirow{2}{*}{ Asperpyrone D (4) } & SCSIO Jcsw6F30 & marine & 29 \\
\hline & $\mathrm{nr}$ & endophyte & 30 \\
\hline Asperpyrone E (5) & SCSIO Jcsw6F30 & marine & 29 \\
\hline \multirow{5}{*}{ Aurasperone A (6) } & IFBE 003 & endophyte & 32 \\
\hline & JV 33-48 & soil & 28 \\
\hline & CMI-IMI 205879 & endophyte & 34 \\
\hline & SCSIO Jcsw6F30 & marine & 29 \\
\hline & EN 13 & marine & 31 \\
\hline \multirow{5}{*}{ Aurasperone B (7) } & MSA 773 & marine & 35 \\
\hline & SCSIO Jcsw6F30 & marine & 29 \\
\hline & EN 13 & marine & 31 \\
\hline & C 433 & endophyte & 36 \\
\hline & BL-5-1 & $\mathrm{nr}$ & 37 \\
\hline \multirow{3}{*}{ Aurasperone C (8) } & SCSIO Jcsw6F30 & marine & 29 \\
\hline & C 433 & endophyte & 36 \\
\hline & BL-5-1 & $\mathrm{nr}$ & 37 \\
\hline \multirow{3}{*}{ Aurasperone D (9) } & CMI-IMI 205879 & endophyte & 34 \\
\hline & $\mathrm{nr}$ & endophyte & 30 \\
\hline & $\mathrm{C} 433$ & endophyte & 36 \\
\hline \multirow{2}{*}{ Aurasperone E (10) } & CMI-IMI 205879 & endophyte & 34 \\
\hline & $\mathrm{C} 433$ & endophyte & 36 \\
\hline \multirow{2}{*}{ Aurasperone F (11) } & SCSIO Jcsw6F30 & marine & 29 \\
\hline & C 433 & endophyte & 36,38 \\
\hline Aurasperone G (12) & C 433 & endophyte & 38 \\
\hline Aurasperone $\mathrm{H}(\mathbf{1 3})$ & 2HL M-8 & marine & 33 \\
\hline 6,9-Dibromoflavasperone (14) & MSA 773 & marine & 35 \\
\hline 6'-O-Demethylnigerone (15) & MRC 278 & endophyte & 39 \\
\hline \multirow{2}{*}{ Dianhydroaurasperone C (16) } & $\mathrm{nr}$ & endophyte & 30 \\
\hline & EN 13 & marine & 31 \\
\hline \multirow{3}{*}{ Flavasperone (17) } & MSA 773 & marine & 35 \\
\hline & CMI-IMI 205879 & endophyte & 34 \\
\hline & TC 1629 & soil & 40 \\
\hline \multirow{5}{*}{ Fonsecin (18) } & MSA 773 & marine & 35 \\
\hline & TC 1629 & soil & 40 \\
\hline & C 433 & endophyte & 36 \\
\hline & SCSIO Jcsw6F30 & marine & 41 \\
\hline & IBT 29019 & endophyte & 42 \\
\hline
\end{tabular}

\begin{tabular}{|c|c|c|c|}
\hline Compound & Strain & Source & Reference \\
\hline Fonsecin B (19) & TC 1629 & soil & 40 \\
\hline \multirow{5}{*}{ Fonsecinone A (20) } & IFBE 003 & endophyte & 32 \\
\hline & JV 33-48 & soil & 28 \\
\hline & SCSIO Jcsw6F30 & marine & 29 \\
\hline & 2HL M-8 & marine & 33 \\
\hline & EN 13 & marine & 31 \\
\hline \multirow{3}{*}{ Fonsecinone B (21) } & SCSIO Jcsw6F30 & marine & 29 \\
\hline & 2HL M-8 & marine & 33 \\
\hline & EN 13 & marine & 31 \\
\hline \multirow{4}{*}{ Fonsecinone C (22) } & SCSIO Jcsw6F30 & marine & 29 \\
\hline & 2HL M-8 & marine & 33 \\
\hline & EN 13 & marine & 31 \\
\hline & SCSIO Jcsw6F30 & marine & 41 \\
\hline \multirow{4}{*}{ Fonsecinone D (23) } & SCSIO Jcsw6F30 & marine & 29 \\
\hline & $2 \mathrm{HL}$ M-8 & marine & 33 \\
\hline & EN 13 & marine & 31 \\
\hline & SCSIO Jcsw6F30 & marine & 41 \\
\hline 2-Hydroxydihydronigerone (24) & AKRN & endophyte & 43 \\
\hline \multicolumn{4}{|l|}{ 5,7-Dihydroxy-2-[1-(4-methoxy- } \\
\hline $\begin{array}{l}\text { 6-oxo-6H-pyran-2-yl)-2-phenyl- } \\
\text { ethylamino]-[1,4]naphthoquinone }\end{array}$ & EN 13 & marine & 44 \\
\hline \multicolumn{4}{|l|}{ (25) } \\
\hline Isoaurasperone (26) & CMI-IMI 205879 & endophyte & 34 \\
\hline \multirow{2}{*}{ Isoaurasperone A (27) } & 2HL M-8 & marine & 33 \\
\hline & $\mathrm{nr}$ & endophyte & 30 \\
\hline Isoaurasperone F (28) & $\mathrm{nr}$ & endophyte & 30 \\
\hline Isonigerone (29) & MRC 278 & endophyte & 39 \\
\hline \multicolumn{4}{|l|}{ Nigerasperone A (30) } \\
\hline Nigerasperone B (31) & EN 13 & marine & 31 \\
\hline \multicolumn{4}{|l|}{ Nigerasperone C (32) } \\
\hline \multirow{2}{*}{ Nigerone (33) } & AKRN & endophyte & 43 \\
\hline & MRC 278 & endophyte & 39 \\
\hline \multirow{2}{*}{ Rubrofusarin (34) } & CMI IMI 205879 & endophyte & 34 \\
\hline & SCSIO Jcsw6F30 & marine & 41 \\
\hline \multirow{3}{*}{ Rubrofusarin B (35) } & IFBE 003 & endophyte & 32 \\
\hline & TC 1629 & soil & 40 \\
\hline & SCSIO Jcsw6F30 & marine & 41 \\
\hline nor-Rubrofusarin (36) & BL 5-1 & $\mathrm{nr}$ & 37 \\
\hline $\begin{array}{l}\text { Rubrofusarin-6- } O-\alpha-\mathrm{D}- \\
\text { ribofuranoside (37) }\end{array}$ & $\mathrm{nr}$ & endophyte & 30 \\
\hline $\begin{array}{l}(R)-10-(3-\text { Succinimidyl)-TMC- } \\
\text { 256A1 (38) }\end{array}$ & $\mathrm{nr}$ & endophyte & 30 \\
\hline \multirow{2}{*}{ TMC-256A1 (39) } & MSA 773 & marine & 35 \\
\hline & TC 1629 & soil & 40 \\
\hline TMC-256C1 (40) & TC 1629 & soil & 40 \\
\hline
\end{tabular}

Potent radical scavenging activity of aurasperone B (7), isolated of a marine-mudflat-derived strain, was reported, ${ }^{35}$ while its analogue aurasperone D (9), produced by a strain isolated from infected mango fruit, showed marked central nervous system depressant effects in albino mice and rats. ${ }^{34}$ Aurasperones $\mathrm{C}$ and $\mathrm{F}$ ( $\mathbf{8}$ and $\mathbf{1 1}$, respectively), both metabolized by a marine strain isolated from the alga

Sargassum sp., exhibited COX-2 inhibitory activities. Notwithstanding, only compound $\mathbf{1 1}$ presented the best inhibitory rates of cytotoxicity when tested against cervical cancer HeLa, breast cancer MCF-7, acute lymphoblastic leukemia Molt-4, hepatocellular carcinoma Huh-7, and lung cancer H1975 cell lines. ${ }^{29}$ Aurasperone H (13), obtained from a marine-derived strain, exhibited moderated 
inhibitory activity against the lung adenocarcinoma A549 and leukemia HL-60 human cell lines. ${ }^{33}$

The chemical study of $A$. niger strain recovered from soil samples collected in Sakai, Japan, yielded asperpyrone A (1) and fonsecinone $\mathrm{A}(\mathbf{2 0})$, which showed inhibitory activity on Taq DNA polymerase. ${ }^{28}$ Additionally, compound $\mathbf{1}$, obtained from a marine strain isolated from alga (Sargassum sp.), also exhibited COX-2-inhibitory activity. ${ }^{29}$ Fonsecinone A (20), produced by an endophyte strain associated to Cynodon dactylon, exhibited growth inhibition against the bacteria Bacillus subtilis, Escherichia coli and Pseudomonas fluorescence, besides the fungi T. rubrum and C. albicans. ${ }^{32}$ 2-Hydroxydihydronigerone (24) was isolated from a strain endophyte associated to Entandrophragma congoense and showed weak antimicrobial activity against Enterobacter aerogenes, Enterobacter cloacae, Klebsiella pneumoniae and E. coli. ${ }^{43}$

The nigerone-type BNPs, which display C-10-C-10' linkage, have more restricted occurrence in A. niger. Nigerone (33) was produced by a strain isolated from the inner tissues of Entandrophragma congoense and showed weak antimicrobial activity on Enterobacter aerogenes, E. cloacae, Klebsiella pneumoniae, and E. coli. ${ }^{43}$ It is noteworthy that derivatives 6'-O-demethylnigerone (15) and isonigerone (29) were so far biosynthesized only by A. niger MRC-278 isolated from infected Mozambican ground nuts. ${ }^{39}$

Monomeric naphtho- $\gamma$-pyrones, such as rubrofusarin B (35), fonsecin (18), fonsecin B (19) and flavasperone (17), were considered intermediates in the biosynthesis of bis-naphtho- $\gamma$-pyrones (BNPs). ${ }^{45}$ These compounds, together with TMC-256 A1 (39) and C1 (40), produced by a soil strain collected in Japan, showed suppression of the production of IgE via inhibition of IL-4 signal transduction and were considered useful models to the treatment of allergic disease. ${ }^{40}$ Rubrofusarin B (35), obtained from an endophytic fungus strain isolated from Cynodon dactylon, also displayed significant inhibitions on $\mathrm{XO}$ with $\mathrm{IC}_{50}$ (half maximal inhibitory concentration) values comparable to that of the positive control allopurinol. In addition, this compound showed significant cytotoxicity against colon cancer cell line SW1116 and growth inhibition against the pathogens C. albicans and T. rubrum. ${ }^{32}$ Strong radical scavenging activities were reported for 6,9-dibromoflavasperone (14), flavasperone (17), fonsecin (18) and TMC-256 A1 (39), isolated from a strain of a marine-mudflat-derived, being more potent than the positive control, acid ascorbic. ${ }^{35}$

\section{2. $\alpha$-Pyrones}

$\alpha$-Pyrones is a class of six-membered unsaturated lactones naturally existing in A. niger as vital biosynthetic intermediates of coumarin ring system (41-60, Figure 3, Table 2). ${ }^{46-52}$ An endophytic strain of the fungus associated to the marine mangrove plant Avicennia marina was source of eight $\alpha$-pyrone derivatives named nigerapyrones $\mathrm{A}-\mathrm{H}$ (51-58), along with the two analogues asnipyrones A (41) and B (42). ${ }^{46}$ Asnipyrone A (41) showed activity against human lung carcinoma cell line A549, while nigerapyrone B (52) displayed selective cytotoxicity activity against human liver cancer HepG2 cell line. Nigerapyrone D (54) showed moderated or weak activity when tested against breast cancer MCF-7, human liver cancer HepG2 and human lung carcinoma A549 cell lines. Nigerapyrone E (55) showed strong cytotoxicity against human pancreatic adenocarcinoma cell line SW1990, breast cancer cell line MDA-MB-231 and human lung carcinoma cell lines A549 but weak or moderate activity against breast cancer MCF-7, human liver cancer HepG2, human prostate cancer Du145 and human lung cancer NCI-H460 cell lines. ${ }^{46}$

Table 2. $\alpha$-Pyrones (41-60) produced by A. niger strains

\begin{tabular}{|c|c|c|c|}
\hline Compound & Strain & Source & Reference \\
\hline Asnipyrone A (41) & \multirow{2}{*}{ MA 132} & \multirow{2}{*}{ marine } & \multirow{2}{*}{46} \\
\hline Asnipyrone B (42) & & & \\
\hline Aspergillusol (43) & EN 13 & marine & 47 \\
\hline \multirow{2}{*}{ Campyrone A (44) } & $\mathrm{nr}$ & endophyte & 48 \\
\hline & CAFT 160 & endophyte & 49 \\
\hline \multirow{2}{*}{ Campyrone B (45) } & CAFT 160 & endophyte & 49 \\
\hline & $\mathrm{nr}$ & endophyte & 48 \\
\hline \multirow{2}{*}{ Campyrone C (46) } & CAFT 160 & endophyte & 49 \\
\hline & $\mathrm{nr}$ & endophyte & 48 \\
\hline $\begin{array}{l}\text { 4-(Hydroxymethyl)-5-hydroxy- } \\
2 H \text {-pyran-2-one (47) }\end{array}$ & AKRN & endophyte & 43 \\
\hline $\begin{array}{l}\text { 4-(Hydroxymethyl)-5,6-dihydro- } \\
\text { pyran-2-one (48) }\end{array}$ & $\mathrm{nr}$ & endophyte & 48 \\
\hline Isopyrophen (49) & EN 13 & marine & 47 \\
\hline Nafuredin (50) & FT 0054 & marine & 50 \\
\hline \multicolumn{4}{|l|}{ Nigerapyrone A (51) } \\
\hline \multicolumn{4}{|l|}{ Nigerapyrone B (52) } \\
\hline \multicolumn{4}{|l|}{ Nigerapyrone C (53) } \\
\hline Nigerapyrone D (54) & \multirow{5}{*}{ MA 132} & \multirow{5}{*}{ marine } & \multirow{5}{*}{46} \\
\hline Nigerapyrone E (55) & & & \\
\hline Nigerapyrone F (56) & & & \\
\hline Nigerapyrone G (57) & & & \\
\hline Nigerapyrone H (58) & & & \\
\hline \multirow{4}{*}{ Pyrophen (59) } & AKRN & endophyte & 43 \\
\hline & UCSC 4-1212 & marine & 51 \\
\hline & ATCC 36533 & $\mathrm{nr}$ & 52 \\
\hline & EN 13 & marine & 47 \\
\hline Walterolactone (60) & $\mathrm{nr}$ & endophyte & 48 \\
\hline
\end{tabular}

Campyrones A-C (44-46) were isolated from an endophyte strain occurring in Zanthoxylum lemairei leaves and exhibited weak toxicity on brine shrimp larvae. ${ }^{49}$ In addition, nafuredin $(\mathbf{5 0})$, obtained from a marine strain 
<smiles>[R]C1=C(OC)CC(/C=C/C(C)=C/C(C)=C/c2ccccc2)OC1=O</smiles>

$41 \mathrm{R}=\mathrm{CH}_{3}, \mathrm{C}-7(E), \mathrm{C}-9(E), \mathrm{C}-11(E)$<smiles>[R]C1=CC(=O)OCC1[R7]</smiles>

$48 \mathrm{R}^{1}=\mathrm{CH}_{2} \mathrm{OH}, \mathrm{R}^{2}=\mathrm{H}$

$60 \mathrm{R}^{1}=\mathrm{CH}_{3}, \mathrm{R}^{2}=\alpha \mathrm{OH}$

$42 \mathrm{R}=\mathrm{H}, \mathrm{C}-7(E), \mathrm{C}-9(E), \mathrm{C}-11(E)$

$56 \mathrm{R}=\mathrm{H}, \mathrm{C}-7(E), \mathrm{C}-9(E), \mathrm{C}-11(\mathrm{Z})$

$57 \mathrm{R}=\mathrm{H}, \mathrm{C}-7(E), \mathrm{C}-9(Z), \mathrm{C}-11(E)$

$58 \mathrm{R}=\mathrm{H}, \mathrm{C}-7(Z), \mathrm{C}-9(E), \mathrm{C}-11(E)$<smiles>CC[C@H](C)/C=C/C=C(\C)C[C@H](C)/C=C/C=C/[C@H]1OC(=O)[C@H](O)[C@H]2O[C@]12C</smiles>

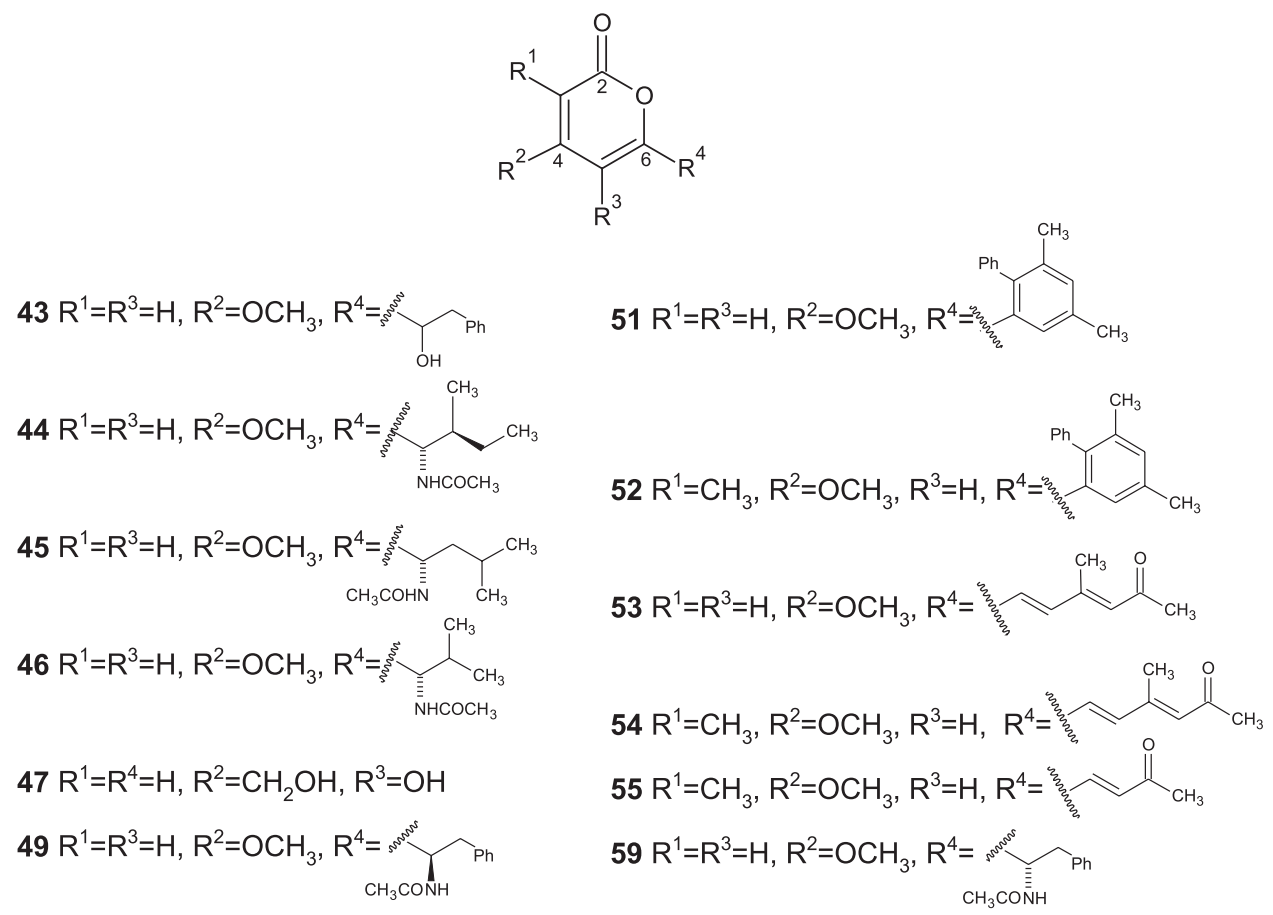

Figure 3. Chemical structures of $\alpha$-pyrones (41-60) produced by A. niger strains.

of the fungus associated to a sponge collected in Palau Islands, exhibited inhibitory activity against Ascaris suum nicotinamide adenine dinucleotide plus hydrogen (NADH)-fumarate reductase, revealing this compound as a potentially selective antiparasitic agent. ${ }^{50}$ It is worth mentioning that pyrophen (59) was the first $\alpha$-pyrone amino acid derivative isolated from fungi. ${ }^{52}$

\subsection{Yanuthones}

Yanuthones (61-79, Figure 4, Table 3 ) are compounds containing core structure constituted of an epoxylated sixmembered ring with a sesquiterpene chain at $\mathrm{C}-13$ and varied side chains at $\mathrm{C}-15$ and $\mathrm{C}-16$. The core structure may be derived from different precursors, which lead to the formation of two classes of yanuthones (I and II). In A. niger, yanuthones from class I are derived from the polyketide 6-methylsalicylic acid (6-MSA), that delivers a C7 scaffold containing a six-membered methylated ring at $\mathrm{C}-16$. Class II yanuthones contain a C6-core scaffold oxygenated at $\mathrm{C}-16$ derived from an unknown precursor..$^{53-55}$

22-Deacetylyanuthone A (62), 1-hydroxyyanuthone A (63), 1-hydroxyyanuthone C (64) and yanuthones A-E (65-69) were biosynthesized by a marine fungal strain associated to the ascidia Aplidium sp. All compounds were tested against Staphylococcus aureus, E. coli, Enterococcus and C. albicans, and the most active compounds ( 68 and 69) 
<smiles>[R]CC(C)=CCCC(C)=CCCC(C)=CC[C@@]12OC1C([R])C([R])=CC2=O</smiles>

$$
\begin{aligned}
& 61 \mathrm{R}^{1}=\mathrm{CH}_{3}, \mathrm{R}^{2}=\beta \mathrm{OH}, \mathrm{R}^{3}=\mathrm{H} \\
& 62 \mathrm{R}^{1}=\mathrm{CH}_{2} \mathrm{OH}, \mathrm{R}^{2}=\beta \mathrm{OH}, \mathrm{R}^{3}=\mathrm{H} \\
& 63 \mathrm{R}^{1}=\mathrm{CH}_{2} \mathrm{OAc}, \mathrm{R}^{2}=\beta \mathrm{OH}, \mathrm{R}^{3}=\mathrm{OH} \\
& 64 \mathrm{R}^{1}=\mathrm{CH}_{2} \mathrm{OH}, \mathrm{R}^{2}=\beta \mathrm{OAc}, \mathrm{R}^{3}=\mathrm{OH} \\
& 65 \mathrm{R}^{1}=\mathrm{CH}_{2} \mathrm{OAc}, \mathrm{R}^{2}=\beta \mathrm{OH}, \mathrm{R}^{3}=\mathrm{H} \\
& 66 \mathrm{R}^{1}=\mathrm{CH}_{2} \mathrm{OAc}, \mathrm{R}^{2}==\mathrm{O}, \mathrm{R}^{3}=\mathrm{H} \\
& 67 \mathrm{R}^{1}=\mathrm{CH}_{2} \mathrm{OH}, \mathrm{R}^{2}=\beta \mathrm{OAc}, \mathrm{R}^{3}=\mathrm{H}
\end{aligned}
$$

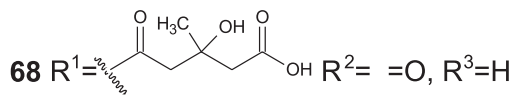

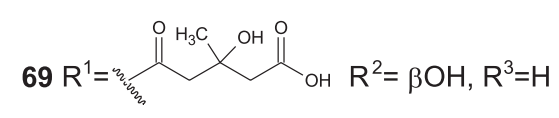

$70 \mathrm{R}^{1}=\mathrm{CH}_{3}, \mathrm{R}^{2}=\beta \mathrm{OH}, \mathrm{R}^{3}=\mathrm{OH}$

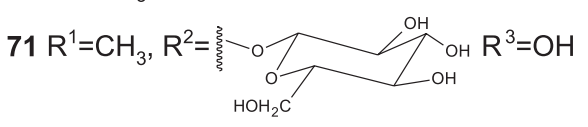

$72 \mathrm{R}^{1}=\mathrm{CH}_{2} \mathrm{OH}, \mathrm{R}^{2}=\beta \mathrm{OH}, \mathrm{R}^{3}=\mathrm{OH}$

$75 \mathrm{R}^{1}=\mathrm{CH}_{3}, \mathrm{R}^{2}=\beta \mathrm{OAC}, \mathrm{R}^{3}=\mathrm{H}$

$76 \mathrm{R}^{1}=\mathrm{CH}_{3}, \mathrm{R}^{2}=\beta \mathrm{OAC}, \mathrm{R}^{3}=\mathrm{OH}$

$78 \mathrm{R}^{1}=\mathrm{OCH}_{3}, \mathrm{R}^{2}=\beta \mathrm{OAC}, \mathrm{R}^{3}=\mathrm{H}$

$79 \mathrm{R}^{1}=\mathrm{OCH}_{3}, \mathrm{R}^{2}=\beta \mathrm{OH}, \mathrm{R}^{3}=\mathrm{H}$

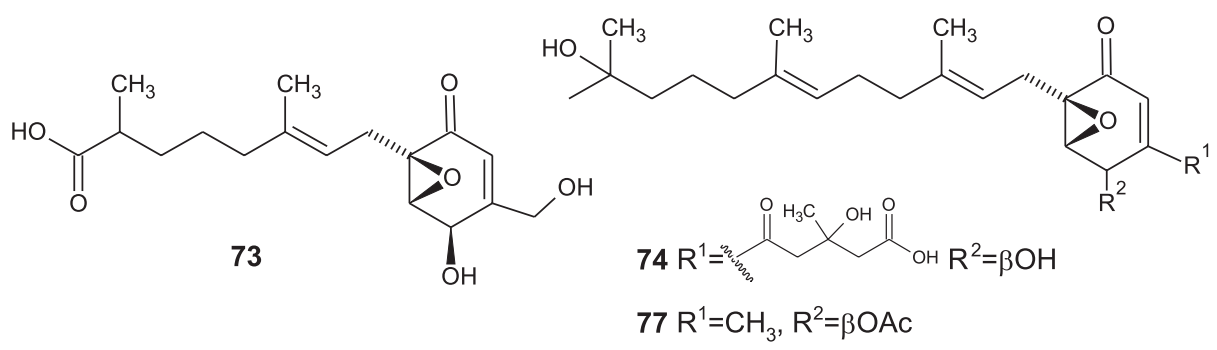

Figure 4. Chemical structures of yanuthones (61-79) produced by A. niger strains.

Table 3. Yanuthones (61-79) produced by A. niger strains

\begin{tabular}{lccc}
\hline Compound & Strain & Source & Reference \\
\hline 7-Deacetoxyyanutone A (61) & BR 1001 & mutant strain & 53 \\
\hline $\begin{array}{l}\text { 22-Deacetylyanuthone A (62) } \\
\text { 1-Hydroxyyanuthone A (63) }\end{array}$ & & & \\
1-Hydroxyyanuthone C (64) & & & \\
Yanuthone A (65) & F 97S11 & marine & 54 \\
Yanuthone B (66) & & & \\
Yanuthone C (67) & & & \\
Yanuthone D (68) & & & \\
Yanuthone E (69) & & & \\
\hline Yanuthone F (70) & & & \\
Yanuthone G (71) & BR 1001 & mutant strain & 53 \\
Yanuthone H (72) & & & \\
Yanuthone I (73) & & & \\
Yanuthone J (74) & & & \\
\hline Yanuthone K (75) & KB 1001 & mutant strain & 55 \\
Yanuthone L (76) & & & 53 \\
Yanuthone M (77) & BR 1001 & mutant strain & 53 \\
\hline Yanuthone X1 (78) & KB 1001 & mutant strain & 55 \\
\hline Yanuthone X2 (79) & &
\end{tabular}

were those containing a hydroxymethyl glutarate (HMG) at position $22 .{ }^{54}$ The genetic and biosynthetic pathway of yanuthone $\mathrm{D}(\mathbf{6 8})$ from $A$. niger was deduced and revealed yanuthones F-J (70-74) besides the first component of class II, named yanuthone X1 (78). ${ }^{53}$ Yanuthones K-M (75-77) and class II yanuthone X2 (79) were produced by A. niger KB 1001 (recipient mutant strain) and considered antimicrobials when tested toward C. albicans. In this case, the structure-activity relationship was investigated and revealed that functionalization at $\mathrm{C}-15$ has significant impact in the antimicrobial activity. $O$-Glycosylation and $O$-acetylation at this carbon increased the antifungal activity when compared with analogues displaying $\mathrm{OH}$ groups. ${ }^{55}$

\subsection{Cyclopeptides}

The cyclopeptides (80-92) produced by A. niger strains are presented in Figure 5 and Table 4, where malformins are the major constituents..$^{30,56-68}$ They are a group of cyclic pentapeptides containing a disulfide bond from two cysteine thiols, that typically induces malformations in bean plants 
and in the curvature of corn roots. ${ }^{56}$ These compounds were originally isolated from fluid culture of A. niger and classified into three sub-groups: malformins A (from A. niger strain 56-39), malformins B (from A. niger strain 56-30) and malformins $\mathrm{C}$ (from A. niger strain AN-1). ${ }^{65}$

Malformin A sub-group consists mainly of malformins MA1-MA4 (82-85), from which MA1 (82), containing five amino acids (L-isoleucine, L-valine, D-leucine, and two D-cysteines), is the most abundant and well-studied representative. Although originally reported from A. niger strain $56-39,{ }^{59}$ malformin $\mathbf{8 2}$ was also produced by various strains of the fungus from different sources and many biological activities were reported for this compound. MA1 (82) exhibited strong cytotoxic effects against various human cancer cell lines related to the inhibiting cell proliferation, inducing apoptosis, arresting the cell cycle and inhibiting cell migration and invasion. ${ }^{67}$ This significant cytotoxic activity was detected for $\mathbf{8 2}$, produced by an endophyte strain associated to the Chinese liverwort Heteroscyphus tener, against the human ovarian carcinoma cell line A2780, lung cancer cell line H1688, a human erythroleukemic cell line K562, human breast carcinoma
Table 4. Cyclopeptides (80-92) produced by A. niger strains

\begin{tabular}{|c|c|c|c|}
\hline Compound & Strain & Source & Reference \\
\hline Beauvericin (80) & \multirow{2}{*}{ DS 3.1} & \multirow{2}{*}{ mutant strain } & \multirow{2}{*}{56} \\
\hline Enniantin B (81) & & & \\
\hline \multirow{5}{*}{ Malformin A1 (82) } & $\mathrm{nr}$ & endophyte & 30 \\
\hline & BRF 074 & marine & 57 \\
\hline & $\mathrm{nr}$ & air & 58 \\
\hline & $56-39$ & soil & 59 \\
\hline & F 7586 & $\mathrm{nr}$ & 60 \\
\hline Malformin A2 (83) & \multirow{3}{*}{$56-39$} & \multirow{3}{*}{ soil } & \multirow{3}{*}{61} \\
\hline Malformin A3 (84) & & & \\
\hline Malformin A4 (85) & & & \\
\hline Malformin B1a (86) & \multirow{6}{*}{$56-30$} & \multirow{6}{*}{ soil } & \multirow{6}{*}{62} \\
\hline Malformin B1b (87) & & & \\
\hline Malformin B2 (88) & & & \\
\hline Malformin B3 (89) & & & \\
\hline Malformin B4 (90) & & & \\
\hline Malformin B5 (91) & & & \\
\hline \multirow{6}{*}{ Malformin C (92) } & SCSIO Jcsw6F30 & marine & 41 \\
\hline & UCSC94-1212 & marine & 51 \\
\hline & FKI 2342 & soil & 63 \\
\hline & $\mathrm{nr}$ & endophyte & 64 \\
\hline & AN-1 & endophyte & 65 \\
\hline & $\mathrm{nr}$ & endophyte & 66 \\
\hline
\end{tabular}

nr: not reported.



$80 \mathrm{R}^{1}=\mathrm{R}^{3}=\mathrm{R}^{5}=\mathrm{Bn}, \mathrm{R}^{2}=\mathrm{R}^{4}=\mathrm{R}^{6}=\mathrm{CH}\left(\mathrm{CH}_{3}\right)_{2}$ $81 R^{1}=R^{2}=R^{3}=R^{4}=R^{5}=R^{6}=C H\left(C_{3}\right)_{2}$

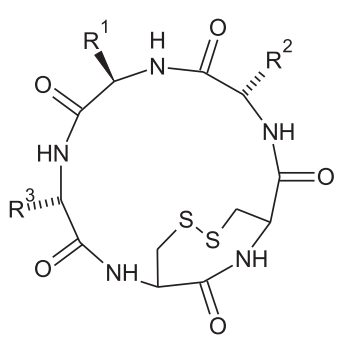

$82 \mathrm{R}^{1}=\mathrm{CH}_{2} \mathrm{CH}\left(\mathrm{CH}_{3}\right)_{2}, \mathrm{R}^{2}=\mathrm{CH}\left(\mathrm{CH}_{3}\right)_{2}$,

$\mathrm{R}^{3}=\mathrm{CH}\left(\mathrm{CH}_{3}\right) \mathrm{CH}_{2} \mathrm{CH}_{3}, \beta \mathrm{S}-\mathrm{S}$

$83 \mathrm{R}^{1}=\mathrm{CH}_{2} \mathrm{CH}\left(\mathrm{CH}_{3}\right)_{2}, \mathrm{R}^{2}=\mathrm{R}^{3}=\mathrm{CH}\left(\mathrm{CH}_{3}\right)_{2}, \beta S-\mathrm{S}$

$84 \mathrm{R}^{1}=\mathrm{R}^{3}=\mathrm{CH}_{2} \mathrm{CH}\left(\mathrm{CH}_{3}\right)_{2}, \mathrm{R}^{2}=\mathrm{CH}\left(\mathrm{CH}_{3}\right)_{2}$, $\beta \mathrm{S}-\mathrm{S}$

$85 \mathrm{R}^{1}=\mathrm{CH}\left(\mathrm{CH}_{3}\right) \mathrm{CH}_{2} \mathrm{CH}_{3}, \mathrm{R}^{2}=\mathrm{R}^{3}=\mathrm{CH}\left(\mathrm{CH}_{3}\right)_{2}$, $\beta S-\mathrm{S}$

$92 \mathrm{R}^{1}=\mathrm{R}^{3}=\mathrm{CH}_{2} \mathrm{CH}\left(\mathrm{CH}_{3}\right)_{2}, \mathrm{R}^{2}=\mathrm{CH}\left(\mathrm{CH}_{3}\right)_{2}, \alpha \mathrm{S}-\mathrm{S}$

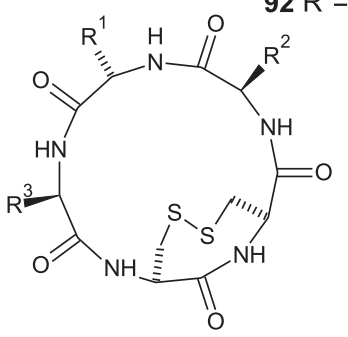

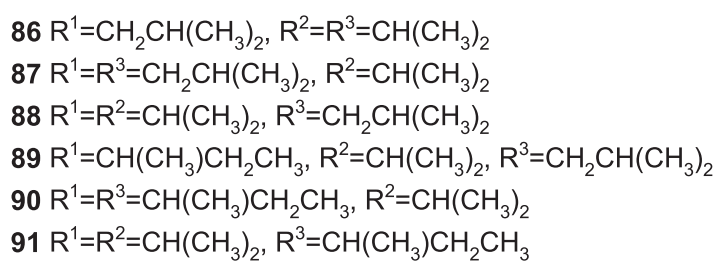

Figure 5. Chemical structures of cyclopeptides (80-92) produced by A. niger strains. 
cell line M231 and prostate cancer PC3 cell line in vitro. ${ }^{30}$ Additionally, the same compound biosynthesized by a marine strain recovered from sediments of the Northeast Brazilian coast was cytotoxic against human colon cancer cell line HCT-116. ${ }^{57}$ The antibacterial effects of MA1 (82) isolated from soil strain on E. coli, S. aureus and Proteus mirabilis, ${ }^{68}$ besides the mammalian toxicity of the same compound produced by a strain isolated from the air in Kochi-Indian were also reported. ${ }^{58}$ In both studies, the authors concluded that the disulfide group plays an important role in auxin metabolism due to interactions with essential thiol compounds. In addition, malformin 82 also showed potent physiological effect by inducing root curvatures in corn and stimulating growth in mung bean hypocotyls through the modulation of the ethylene production. ${ }^{59}$ More recently, MA1 from a soil strain collected in Okinawa, Japan, enhanced the fibrinolytic bioactivity, affecting the cell-mediated response to initiate and/or propagate the activity, and its effect appeared to be unique among the known active agents. ${ }^{60}$

Among malformins B isolated from A. niger strain 56-30, malformin B1a (86) showed optimum curvature activity in the corn root test, while analogues B1b (87) and B2 (88) presented lower activities. ${ }^{62}$ Malformin C $(\mathbf{9 2})$, produced by a marine strain associated to the alga Sargassum sp., exhibited potent HIV-1 inhibitory activity and was considered a promising anti-HIV lead drug. ${ }^{41}$ The same compound biosynthesized by a strain recovered from soil collected at Nagasaki, Japan, was effective against bleomycin-induced G2 arrest in adenocarcinoma HCT-116 cell line. ${ }^{63}$ Moreover, malformin 92, produced by A. niger strain isolated from mold-damaged rice in Thailand, presented antibacterial activity against B. subtilis, B. megaterium, S. aureus, Streptococcus faecalis, Proteus mirabilis and Sarcina lutea, ${ }^{64}$ and induced grown abnormalities similar to MA1 (82). ${ }^{65}$

\subsection{Pyranonigrins}

Pyranonigrins are compounds with a unique pyrano[3,2-b]pyrrole bicyclic skeleton (93-105, Figure 6, Table 5) that are restricted to A. niger strains. ${ }^{69-72}$ Pyranonigrins A-D (93-96) were biosynthesized by the fungus associated to the Mediterranean sponge Axinella damicornis. $^{70}$ These compounds, besides pyranonigrin $\mathrm{S}$ (105), were also produced by A. niger LL-LV3020 grown on solid culture. ${ }^{72}$ Gene knockout and transcriptional activation of the pyranonigrin biosynthetic gene cluster in A. niger ATCC 1015, besides in vitro and in vivo assays, allowed the isolation of pyranonigrin E1 (97) and F-K (99-104), and contributed to the understanding of pyranonigrin biosynthetic pathway. ${ }^{71}$ Pyranonigrin A (93), E2 (98) and
S (105), exhibited a high level of 1,1-diphenyl-2-picrylhydrazyl (DPPH) radical scavenging activity. ${ }^{72}$

\subsection{Diketopiperazines}

Diketopiperazines (DKPs) are the smallest constrained cyclic peptide consisting of heterocyclic molecules with the double lactam core structure formed by cyclization of two alpha-amino acids. The cyclization leads to the formation of three regioisomers, 2,3-DKP, 2,5-DKP, and 2,6-DKP, based on the relative position of the carbonyl groups. 2,5-DKPs are the best-known group in the field of chemistry and are the only DKP-type found in A. niger (106-117, Figure 7, Table 6). ${ }^{47,48,51,57,73}$ Asperazine (106), the first diketopiperazine heterodimer, was isolated from a marine strain associated to a Caribbean Hyrtios sponge. This compound displayed an unusual profile of cytotoxicity by significant selective activity against human leukemia murine colon 38 and human colon $\mathrm{H} 116$ or CX1 cell lines. ${ }^{73}$ In addition, 106, asperazine A (107), cyclo(D-Phe-L-Trp) (108) and cyclo(L-Trp-L-Trp) (114) were produced by the endophytic fungus from Heteroscyphus tener. Among these compounds, asperazines $\mathbf{1 0 6}$ and $\mathbf{1 0 7}$ showed weak cytotoxicity against ovarian cancer cell line A2780. ${ }^{48}$

It is worth mentioning that, despite the reports on the occurrence of DKPs in A. niger strains, in a recent review article $^{74}$ the authors question the origin of compounds asperazine 106, asperazine A (107), cyclo(D-Phe-L-Trp) (108), cyclo(L-Trp-L-Trp) (114) besides campyrones A-C (44-46) and walterolactone $\mathrm{A}(\mathbf{6 0})$ as being from A. niger. This is because some strains that biosynthesized these compounds were re-classified as A. tubingensis which is known to produce them.

\subsection{Itaconic acid derivatives}

Itaconic acid (122) is an unsaturated C5 dicarboxylic acid used worldwide as monomer or co-monomer in the polymer industry. Although it was produced commercially by $A$. terreus, strains of $A$. niger have been selected as novel itaconic acid and derivatives producer using genetic modification and medium optimization (118-128, Figure 8, Table 7). ${ }^{77,78,80}$ Hexylitaconic acid (121), produced by a marine strain isolated from sponge Hyrtios proteus, ${ }^{51}$ and from $A$. niger $\mathrm{K}-88,{ }^{76}$ was reported as plant growth regulator. Asperitaconic acids A-C (118-120), also produced by a marine strain, associated to the sponge Haliclona sp. from Hainan, China, exhibited antibacterial effect against $S$. aureus. ${ }^{75}$ Tensyuic acids A-F (122-128), metabolized by a fungus strain recovered from soil collected in Nagasaki, Japan, were the first compounds belonging to the itaconic 
<smiles>[R]C=Cc1oc2c(c(=O)c1O)C(=O)N([R])C2([R])[R]</smiles>
<smiles></smiles>

$99 \mathrm{R}^{1}=\left(\mathrm{CH}_{2}\right)_{4} \mathrm{CH}_{3}$

Figure 6. Chemical structures of pyranonigrins (93-105) produced by A. niger strains.

Table 5. Pyranonigrins (93-105) produced by A. niger strains

\begin{tabular}{lccc}
\hline Compound & Strain & Source & Reference \\
\hline Pyranonigrin A (93) & LL-LV 3020 & marine & 69 \\
CBX 146 2002 & marine & 70 \\
\hline $\begin{array}{l}\text { Pyranonigrin B (94) } \\
\text { Pyranonigrin C (95) }\end{array}$ & CBX 146 2002 & marine & 70 \\
Pyranonigrin D (96) & & & \\
\hline Pyranonigrin E1 (97) & A 1179 & mutant strain & 71 \\
\hline Pyranonigrin E2 (98) & NBRC 5374 & nr & 72 \\
\hline Pyranonigrin F (99) & & & \\
Pyranonigrin G (100) & & & \\
Pyranonigrin H (101) & A 1179 & mutant strain & 71 \\
Pyranonigrin I (102) & & & \\
Pyranonigrin J (103) & & & \\
Pyranonigrin K (104) & & marine & \\
\hline Pyranonigrin S (105) & LL-LV 3020 &
\end{tabular}

nr: not reported

acid family containing ester carboxyl moieties at the end of the alkyl side chain. Among them, tensyuic acid C (125) showed moderate antimicrobial activity against $B$. subtilis. ${ }^{79}$

\subsection{Terpenes}

Terpenes have limited occurrence to volatile compounds<smiles>[R]c1c([R])n([R])c2c(=O)c(O)c(/C=C/C)oc12</smiles>

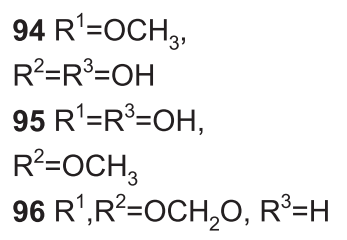


<smiles>[R][C@]12C[C@H]3C(=O)N[C@@H](Br)C(=O)N3[C@H]1Nc1ccccc12</smiles><smiles>[B][C@H]1NC(=O)[C@H](Cc2c[nH]c3c(C(C)C)cccc23)NC1=O</smiles><smiles></smiles><smiles>[R]C1NC(=O)[C@H](Cc2c[nH]c3ccccc23)NC1=O</smiles>

$108 \mathrm{R}^{1}=\beta \mathrm{Bn}$

$112 \mathrm{R}^{1}=\mathrm{CH}\left(\mathrm{CH}_{3}\right) \mathrm{CH}_{2} \mathrm{CH}_{3}$ $113 \mathrm{R}^{1}=\alpha \mathrm{Bn}$<smiles></smiles>

$115 \mathrm{R}^{1}=\mathrm{CH}_{2}-\mathrm{C}_{6} \mathrm{H}_{4} 4-\mathrm{OH}$<smiles>[R]C1CC2C(=O)NC([R])C(=O)N2C1</smiles>

$109 \mathrm{R}^{1}=\mathrm{H}, \mathrm{R}^{2}=\mathrm{CH}_{2} \mathrm{CH}\left(\mathrm{CH}_{3}\right)_{2}$ $110 \mathrm{R}^{1}=\mathrm{H}, \mathrm{R}^{2}=\mathrm{Bn}$ $111 \mathrm{R}^{1}=\mathrm{H}, \mathrm{R}^{2}=\mathrm{CH}_{2}-\mathrm{C}_{6} \mathrm{H}_{4} 4-\mathrm{OH}$ $116 \mathrm{R}^{1}=\mathrm{OH}, \mathrm{R}^{2}=\mathrm{CH}_{2} \mathrm{CH}\left(\mathrm{CH}_{3}\right)_{2}$ $117 \mathrm{R}^{1}=\mathrm{OH}, \mathrm{R}^{2}=\mathrm{Bn}$

Figure 7. Chemical structures of diketopiperazines (106-117) produced by A. niger strains.

Table 6. Diketopiperazines (106-117) produced by A. niger strains

\begin{tabular}{lccc}
\hline Compound & Strain & Source & Reference \\
\hline & $\mathrm{nr}$ & endophyte & 48 \\
Asperazine (106) & UCSC 94-1212 & marine & 51 \\
& $\mathrm{nr}$ & marine & 73 \\
\hline Asperazine A (107) & $\mathrm{nr}$ & endophyte & 48 \\
Cyclo-(D-Phe-L-Trp) (108) & & & \\
\hline Cyclo-(L-Pro-L-Leu) (109) & & marine & 57 \\
$\begin{array}{l}\text { Cyclo-(L-Pro-L-Phe) (110) } \\
\text { Cyclo-(L-Pro-L-Tyr) (111) }\end{array}$ & BRF 074 & \\
\hline $\begin{array}{l}\text { Cyclo-(L-Trp-L-Ile) (112) } \\
\text { Cyclo-(L-Trp-L-Phe) (113) }\end{array}$ & EN 13 & marine & 47 \\
\hline Cyclo-(L-Trp-L-Trp) (114) & $\mathrm{nr}$ & endophyte & 48 \\
\hline Cyclo-(L-Trp-L-Tyr) (115) & EN 13 & marine & 47 \\
\hline $\begin{array}{l}\text { Cyclo-(trans-4-hydroxy-L-Pro- } \\
\text { L-Leu) (116) }\end{array}$ & & & \\
$\begin{array}{l}\text { Cyclo-(trans-4-hydroxy-L-Pro- } \\
\text { L-Phe) (117) }\end{array}$ & BRF 074 & marine & 57 \\
\hline nr: not reported & & & \\
\hline
\end{tabular}

A. niger strain isolated from the mangrove plant Avicennia marina. Noteworthy is the fact of only five 5,9-epidioxysterols were reported from edible mushrooms before..$^{83}$ It was found that both nigerasterols (144 and 145) displayed potent activity against the human leukemia cell line HL60 and human lung adenocarcinoma cell line A549. Preliminary structure-activity relationship studies speculated that the $\alpha-\mathrm{OH}$ at $\mathrm{C} 15$ in compound $\mathbf{1 4 4}$ could be responsible for its stronger activity than that from compound $\mathbf{1 4 5}$ which displays a $\beta-\mathrm{OH}$ group at the same carbon. ${ }^{83}$

\subsection{Azaphilones}

Azaphilones are pyrone-quinone structures containing a highly oxygenated bicyclic core and a chiral quaternary center. This class of compounds had its first occurrence in A. niger through the study of an activated azaphilone gene cluster in ATCC 1015 strain, which led to the obtention of six new azanigerones A-F (146-151, Figure 11). Additionally, this investigation allowed the authors ${ }^{84}$ to identify the flavin adenine dinucleotide (FAD)-dependent hydroxylase as responsible for the formation of the bicyclic core characteristic of this class of compounds. Among the reported compounds, azanigerone D (149) is the only representative that contains a nitrogen-containing heterocycle at the main core.<smiles>[R]C(C(=C)C(=O)O)C(=O)O</smiles>

$$
\begin{array}{ll}
118 \mathrm{R}^{1}=\left(\mathrm{CH}_{2}\right)_{6} \mathrm{OH}, \mathrm{R}^{2}=\mathrm{CH}_{3} & 123 \mathrm{R}^{1}=\left(\mathrm{CH}_{2}\right)_{3} \mathrm{CO}_{2} \mathrm{CH}_{3}, \mathrm{R}^{2}=\mathrm{CH}_{3} \\
119 \mathrm{R}^{1}=\left(\mathrm{CH}_{2}\right)_{6} \mathrm{OAc}, \mathrm{R}^{2}=\mathrm{H} & 124 \mathrm{R}^{1}=\left(\mathrm{CH}_{2}\right)_{5} \mathrm{CO}_{2} \mathrm{CH}_{3}, \mathrm{R}^{2}=\mathrm{H} \\
120 \mathrm{R}^{1}=\left(\mathrm{CH}_{2}\right)_{4} C O C \mathrm{CO}_{3}, \mathrm{R}^{2}=\mathrm{H} & 125 \mathrm{R}^{1}=\left(\mathrm{CH}_{2}\right)_{5} \mathrm{CO}_{2} \mathrm{CH}_{2} \mathrm{CH}_{3}, \mathrm{R}^{2}=\mathrm{H} \\
121 \mathrm{R}^{1}=\left(\mathrm{CH}_{2}\right)_{5} \mathrm{CH}_{3}, \mathrm{R}^{2}=\mathrm{H} & 126 \mathrm{R}^{1}=\left(\mathrm{CH}_{2}\right)_{5} \mathrm{CO}_{2} \mathrm{CH}_{3}, \mathrm{R}^{2}=\mathrm{CH}_{3} \\
122 \mathrm{R}^{1}=\mathrm{R}^{2}=\mathrm{H} & 127 \mathrm{R}^{1}=\left(\mathrm{CH}_{2}\right)_{7} \mathrm{CO}_{2} \mathrm{CH}_{3}, \mathrm{R}^{2}=\mathrm{H} \\
& 128 \mathrm{R}^{1}=\left(\mathrm{CH}_{2}\right)_{3} \mathrm{CO}_{2} \mathrm{CH}_{2} \mathrm{CH}_{3}, \mathrm{R}^{2}=\mathrm{CH}_{3}
\end{array}
$$

Figure 8. Chemical structures of itaconic acids (118-128) produced by A. niger strains. 
Table 7. Itaconic acids (118-128) produced by $A$. niger strains

\begin{tabular}{lccc}
\hline Compound & Strain & Source & Reference \\
\hline Asperitaconic acid A (118) & & & \\
Asperitaconic acid B (119) & LS 11 & marine & 75 \\
Asperitaconic acid C (120) & & & \\
\hline Hexylitaconic acid (121) & UCSCm 94-1212 & marine & 51 \\
\hline Itaconic acid (122) & K 88 & soil & 76 \\
\hline Tensyuic acid A (123) & AB1 13 & mutant & 77,78 \\
Tensyuic acid B (124) & & & \\
Tensyuic acid C (125) & & & \\
Tensyuic acid D (126) & FKI 2342 & soil & 79 \\
Tensyuic acid E (127) & & & \\
Tensyuic acid F (128) & & & \\
\hline
\end{tabular}

\subsection{Bicoumarins}

Bicoumarins produced by $A$. niger consist of a group of heterocycle dimers derived from cinnamic acid lactone that are further categorized by the type of connection between the coumarins moieties (152-155, Figure 12, Table 10). ${ }^{70,85-87}$ A marine strain isolated from the Mediterranean sponge Axinella damicornis yielded the bicoumanigrin A (152) that showed moderate antiproliferative activity toward a panel of 10 different human leukemia and carcinoma cell lines. ${ }^{70}$ Orlandin (155) (both C8-C8') was produced by a strain isolated from orange leaves in Florida, USA, and significantly inhibited wheat coleoptile growth. ${ }^{87}$

\subsection{Pigments}

Only four compounds (156-159, Figure 13, Table 11) considered by the authors ${ }^{70,88-91}$ as pigments were reported for A. niger. Aspergillin (157) is the native black spore
Table 8. Terpenes (129-138) produced by A. niger strains

\begin{tabular}{lllr}
\hline Compound & Strain & Source & Reference \\
\hline 6,11-Epoxy-isodaucane (129) & & & \\
Geosmin (130) & & & \\
Germacra-[1(10)E,5E]-dien-11-ol (131) & & & \\
Germacrene D (132) & & & \\
$(1 S, 6 S, 10 S)$-6,10-Dimethylbicyclo[4.4.0] & & & \\
dec-2-en-4-one (133) & AB1.13 & mutant strain & \\
$(6 S, 10 S)$-6,10-Dimethylbicyclo[4.4.0]dec- & & & \\
1-en-3-one (134) & & & \\
2-Methylisoborneol (135) & & & \\
(8S,10S)-8,10-Dimethyl-1 (9)-octalin (136) & & \\
$\beta$-Copaene (137) & & \\
$\beta$-Ylangene (138) & & \\
\hline
\end{tabular}

pigment of A. niger that was extensively studied and showed enzymatic proteolytic activity. ${ }^{91}$ On the other hand, the polyene asperenone (156) is a yellow pigment which was isolated from A. niger mycelium and displayed inhibitory activities against soybean lipoxygenase (15-LOX) and platelet aggregation. ${ }^{89}$ This pigment and another yellow pigment named asperrubrol (158) were biosynthesized by an A. niger strain cultured on synthetic medium containing toxic concentrations of $\mathrm{Zn}^{+2}$ and $\mathrm{Cd}^{+2}$ and high concentration of $\mathrm{Mg}^{+2} .{ }^{90}$ In addition, the deep green color pigment cycloleucomelone (159) was identified in the mycelium of a marine strain associated to the Mediterranean sponge Axinella damicornis. ${ }^{70}$

\subsection{Sphingolipids}

Sphingolipids containing unprecedent 9-methylC20-sphingosine moiety were found in A. niger (160-163, Figure 14). ${ }^{92,93}$ Asperamides A (160) and B (161), a sphingolipid and its corresponding glycosphingolipid,<smiles>C[C@@H]1CCC[C@@]2(C)CCC3[C@H]2[C@@H]1OC3(C)C</smiles>

129<smiles>[R]C1([R])C[C@]2(C)CCC[C@H](C)[C@@]2([R])CC1([R])C</smiles>

$130 \mathrm{R}^{1}=\mathrm{R}^{2}=\mathrm{R}^{3}=\mathrm{R}^{4}=\mathrm{H}, \mathrm{R}^{5}=\mathrm{OH}$ $133 R^{1}, R^{2}==O, R^{3}=R^{4}=R^{5}=H, \Delta^{6-7}$

<smiles>[R]C([R])(/C=C/[C@H](CC/C=C(/C)CCC=C)C([R])(C)C)CC=C</smiles>

$$
\begin{aligned}
& 134 R^{1}, R^{2}==0 \\
& 136 R^{1}=R^{2}=H
\end{aligned}
$$<smiles>[R]C1([R])C=C2[C@@H](C)CCC[C@]2(C)CC1</smiles>

$$
131 \mathrm{R}^{1}=\mathrm{CH}_{3}, \mathrm{R}^{2}=\mathrm{H}, \mathrm{R}^{3}=\mathrm{OH}
$$$$
132 \mathrm{R}^{1}, \mathrm{R}^{2}==\mathrm{CH}_{2}, \mathrm{R}^{3}=\mathrm{H}
$$<smiles>CC1(C)C[C@]2(C)CC[C@H]1C[C@@]2(C)O</smiles>

135

Figure 9. Chemical structures of terpenes (129-138) produced by A. niger strains. 


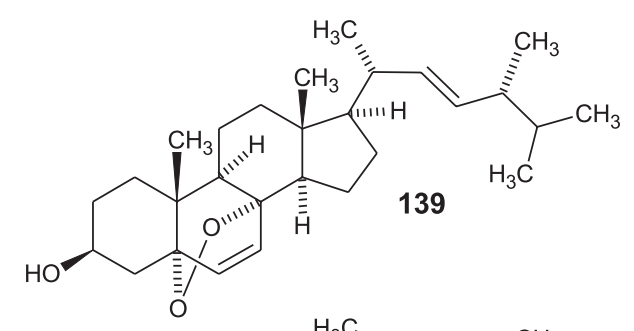<smiles>CC(C)C(C)/C=C/[C@@H](C)[C@H]1CCC2=C3C=CC4=CC(=O)CC[C@]4(C)[C@H]3CC[C@]21C</smiles><smiles>CC(C)C(C)/C=C/[C@@H](C)[C@H]1CC[C@H]2C3=CC=C4C[C@@H](O)CC[C@]4(C)[C@H]3CC[C@]21C</smiles><smiles>CC(C)[C@H](C)/C=C/[C@H](C)[C@H]1CC[C@H]2C3=C[C@H](O)[C@@]4(O)C[C@@H](O)CC[C@]4(C)[C@H]3CC[C@@]21C</smiles>

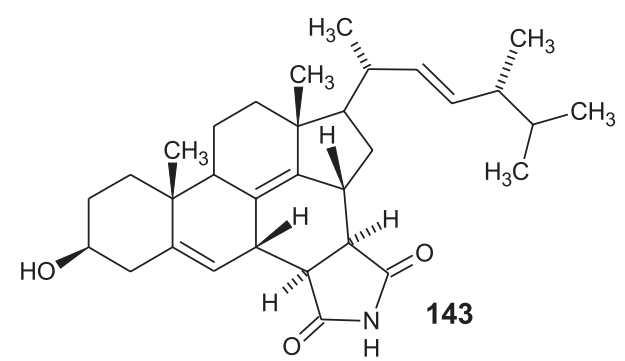

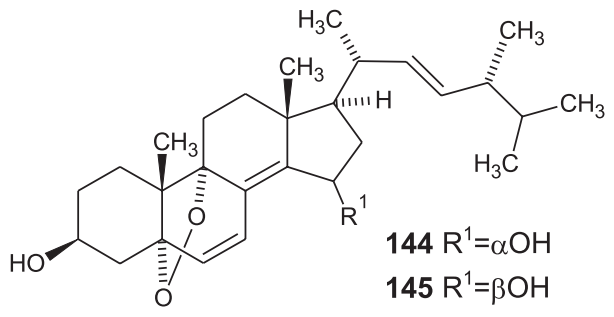

Figure 10. Chemical structures of steroids (139-145) produced by A. niger strains.

Table 9. Steroids (139-145) produced by A. niger strains

\begin{tabular}{|c|c|c|c|}
\hline Compound & Strain & Source & Reference \\
\hline$(22 E, 24 R)-5 \alpha, 8 \alpha$-Epidioxyergosta- & \multirow{9}{*}{ EN 13} & \multirow{9}{*}{ endophyte } & \multirow{9}{*}{82} \\
\hline 6,22-dien-3ß-ol (139) & & & \\
\hline$(22 E, 24 R)$-Ergosta-4,6,8(14),22-tetraen- & & & \\
\hline 3-one (140) & & & \\
\hline$(22 E, 24 R)$-Ergosta-5,7,22-trien-3 3 -ol & & & \\
\hline (141) & & & \\
\hline$(22 E, 24 R)$-Ergosta-7,22-dien- & & & \\
\hline $3 \beta, 5 \alpha, 6 \beta$-triol $(\mathbf{1 4 2})$ & & & \\
\hline Ergosterimide (143) & & & \\
\hline Nigerasterol A (144) & \multirow{2}{*}{ MA 132} & \multirow{2}{*}{ endophyte } & \multirow{2}{*}{83} \\
\hline Nigerasterol B (145) & & & \\
\hline
\end{tabular}

respectively, possessing a hitherto unreported 9-methylC20-sphingosine moiety, were first characterized from an endophytic strain isolated from the marine brown alga Colpomenia sinuosa (EN 13). Among these isolated compounds, asperamide A (160) displayed moderate activity against $C$. albicans..$^{92}$ Asperiamides B (162) and $\mathrm{C}$ (163) were produced by $A$. niger isolated from seawater collected in Fujian Province in China (MF 16) ${ }^{93}$ However, in a recent review ${ }^{74}$ the authors pointed out that the same strain was able to produce the aflatoxin precursors averufin and nidurufin and suggested that this strain was probably A. flavus instead of A. niger.

\subsection{Miscellaneous}

The miscellaneous group comprises those less representative or unique compounds (164-213, Figure 15, Table 12). ${ }^{41-43,57,69,70,81,84,93-112}$ Antafumicins A (166) and B (167), isolated from a collection A. niger strain, inhibited the germination of the fungi Colletotrichum lagenarium, Pyricularia oryzae, Fusarium oxysporum and Botrytis cinerea, as well as the bacteria B. subtilis, E. coli and Aeromonas liquefaciens. ${ }^{95}$ Aspernigrin B (172) was obtained from a marine strain isolated from the sponge Axinella damicornis and displayed a pronounced neuroprotective effect against glutamic acid. ${ }^{70}$ Aspernigrin $\mathrm{C}(\mathbf{1 7 3})$, produced by a marine strain associated to an alga Sargassum sp. collected in south China sea, exhibited significant HIV-1 inhibitory activities by SF162 infection in TZM-bl cells. ${ }^{41}$ Nigerloxin (202) showed dose-dependent aldose reductase activity (rat lens aldose reductase (RLAR)), inhibition against soy bean (lipoxygenase-1 (LOX-1)) and free radical scavenging activity. ${ }^{109}$ Asperaldin (168) showed aldose reductase inhibition (RLAR), ${ }^{96}$ while 2-(2'-methyl, 4'-hydroxyphenyl)2-(4"'-hydroxyphenyl)-propane (196) showed inhibition (RLAR) of lipoxygenase-1 (LOX-1). ${ }^{106}$ Funalenone (183), produced by a strain recovered from soil collected in Funabashi, Japan, inhibited type I collagenase activity dose-dependently, ${ }^{100}$ and the furan 


$$
\begin{aligned}
& 150 \mathrm{R}^{1}=\mathrm{OH}, \mathrm{R}^{2}=\mathrm{CH}_{2}(\mathrm{CH}) \mathrm{OHCH}_{3} \\
& 151 \mathrm{R}^{1}=\mathrm{OAC}, \mathrm{R}^{2}=\mathrm{CH}_{2}(\mathrm{CH}) \mathrm{OHCH}_{3}
\end{aligned}
$$

Figure 11. Chemical structures of azaphilones (146-151) produced by A. niger strains.<smiles>COc1cc(C)c2c(OC)c(-c3c(O)c4c(C)cc(O)cc4oc3=O)c(=O)oc2c1</smiles>

152<smiles></smiles>

Figure 12. Chemical structures of bicoumarins (152-155) produced by A. niger strains.

Table 10. Bicoumarins (152-155) produced by A. niger strains

\begin{tabular}{lccc}
\hline Compound & Strain & Source & Reference \\
\hline Bicoumanigrin A (152) & CBX 146 2002 & marine & 70 \\
Demethylkotanin (153) & $\mathrm{nr}$ & $\mathrm{nr}$ & 85 \\
Kotanin (154) & ATCC 36626 & $\mathrm{nr}$ & 86 \\
Orlandin (155) & ATCC 36626 & $\mathrm{nr}$ & 86 \\
& ATCC 36626 & endophyte & 87 \\
\hline
\end{tabular}

ester compound $\mathbf{1 8 4}$, isolated from a marine strain recovered from sediments collected in the Brazilian coast, was cytotoxic against HCT-116 cell line. ${ }^{57}$ Compounds p-methoxyphenylacetic acid (192), phenoxyacetic acid (207), phenylacetic acid (208) and 2-pheynylethanol (209) were produced by a strain isolated from decaying platelets of Kalanchoe daigremontiana and inhibited the germination of cress and lettuce seeds. ${ }^{104}$ In addition, the furopyrrols, tensidols A (212) and B (213) potentiated miconazole activity against $C$. albicans and moderated activity against Pyricularia oryzae, ${ }^{112}$ and aspernigerin (170) showed cytotoxicity against tumor cell lines nasopharyngeal epidermoid KB, cervical carcinoma Hela, and colorectal carcinoma SW1116. ${ }^{97}$

In summary, the literature survey on the secondary metabolites produced by A. niger revealed that NGPs are the major compounds, of which dimeric BNGPs are the most abundant. Pyranonigrins are restricted to A. niger and, together with yanuthones and steroids, these compounds were isolated only from marine strains of this fungus. Most of compounds were produced from strains collected in two or more different habitats, leading to the understanding that the environmental conditions frequently did not alter the metabolism of this fungus. The large miscellaneous group reveals the great versatility of this microorganism to produce secondary metabolites. 


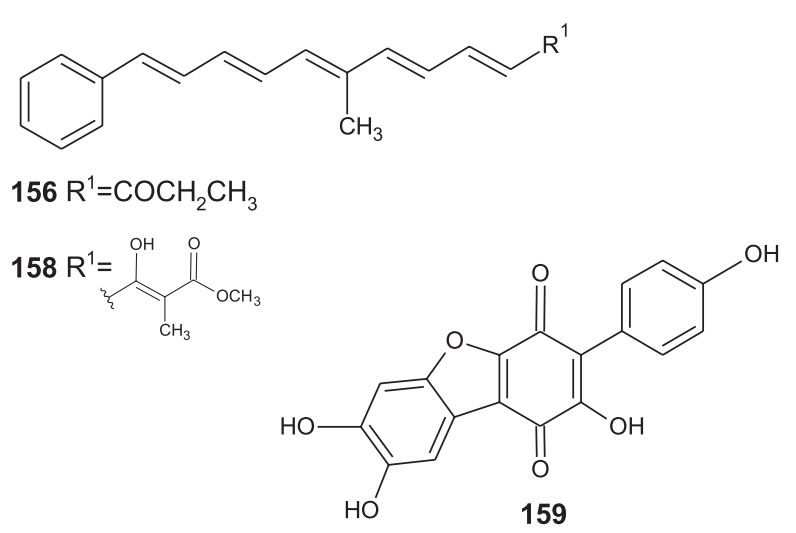<smiles></smiles>

Figure 13. Chemical structures of pigments (156-159) produced by A. niger strains.

Table 11. Pigments (156-159) produced by A. niger strains

\begin{tabular}{lccc}
\hline Compound & Strain & Source & Reference \\
\hline Asperenone (156) & NRRL 3 & $\mathrm{nr}$ & 88 \\
& CFTRI 1105 & $\mathrm{nr}$ & 89 \\
& ATCC 9029 & $\mathrm{nr}$ & 90 \\
Aspergillin (157) & $\mathrm{nr}$ & $\mathrm{nr}$ & 91 \\
Asperrubrol (158) & ATCC 9029 & $\mathrm{nr}$ & 90 \\
Cycloleucomelone (159) & CBX 146 2002 & marine & 70 \\
\hline
\end{tabular}

nr: not reported.<smiles>[R]C=C[C@@H](O)C(=O)N[C@H]([C@H]([R9])O)[C@@H](O)/C=C/CCC=C([R])C</smiles>

$160 \mathrm{R}^{1}=\mathrm{H}, \mathrm{R}^{2}=\left(\mathrm{CH}_{2}\right)_{11} \mathrm{CH}_{3}, \mathrm{R}^{3}=\left(\mathrm{CH}_{2}\right)_{10} \mathrm{CH}_{3}$

$161 \mathrm{R}^{1}=\beta$-D-glucopyranoside, $\mathrm{R}^{2}=\left(\mathrm{CH}_{2}\right)_{11} \mathrm{CH}_{3}, \mathrm{R}^{3}=\left(\mathrm{CH}_{2}\right)_{10} \mathrm{CH}_{3}$ $163 \mathrm{R}^{1}=\beta$-D-glucopyranoside, $\mathrm{R}^{2}=\left(\mathrm{CH}_{2}\right)_{11} \mathrm{CH}_{3}, \mathrm{R}^{3}=\left(\mathrm{CH}_{2}\right)_{12} \mathrm{CH}_{3}$

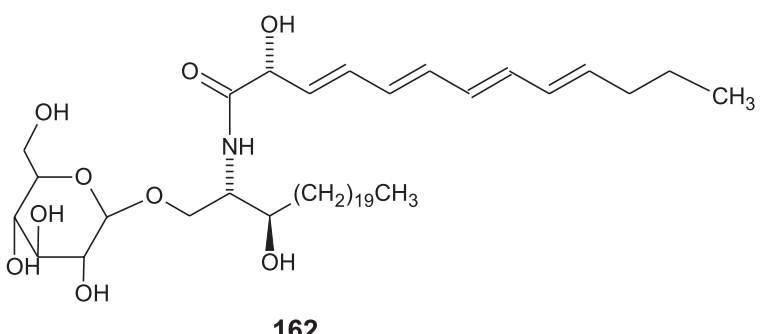

Figure 14. Chemical structures of sphingolipids $(\mathbf{1 6 0 - 1 6 3 )}$ produced by A. niger strains.

\section{Mycotoxins from A. niger Strains}

Mycotoxins are a special group of secondary metabolites that are toxic and present health hazards or death in vertebrates if naturally taken (orally, by inhalation, or via the skin) even in low concentrations. ${ }^{74}$ Although considered a ubiquitous innocuous contaminant, only a few cases of toxins formation in A. niger were reported ${ }^{74,113}$ and medical cases of opportunistic diseases and hypersensitivity reactions involving this fungus were observed only in persons with severe illness or during immunosuppressive treatment. ${ }^{113}$ Thus, A. niger is generally regarded as a nonpathogenic fungus to humans and it received the GRAS (generally regarded as safe) status by the Joint FAO/WHO Expert Committee of Food Additives. ${ }^{27}$

Fumonisins (214-216), gliotoxin (217) and ochratoxins (218-220) (Figure 16, Table 13), are the only mycotoxins reported for A. niger so far. The production of these toxic compounds was considered strain-specific and environmental-dependent and many culture parameters were investigated. ${ }^{114,118,120-122}$

For many years, fumonisins were known as carcinogenic mycotoxins reported only from Fusarium species. ${ }^{123}$ However, studies of genome sequence identified a putative gene cluster for fumonisin biosynthesis in A. niger and, since then, fumonisin production has been produced by several $A$. niger isolates that came from culture collections of commercial foods. ${ }^{74}$ Fumonisins B2 (214), B4 (215) and B6 (216) $)^{66,74,115,116}$ were produced by strains from cereals, coffees and grapes, ${ }^{74,114,124}$ and by strains of industrial use. ${ }^{74}$ However, some industrial strains were developed, and they are currently in use, by classical mutagenesis through which the genes involved in the biosynthesis of fumonisins were deleted. $^{125}$

Ochratoxin A (OTA) (218) was originally isolated from a strain of $A$. ochraceus in 1965, but during the subsequent years, a great variety of $A$. niger strains were considered as the main responsible for contamination of grapes by OTA worldwide. ${ }^{66,126}$ OTA is the major clinically relevant 
mycotoxin that causes immunosuppressive, teratogenic, neurotoxic, genotoxic, mutagenic and carcinogenic effects. ${ }^{127}$ Ochratoxin $\alpha($ OT $\alpha)($ 219) and ochratoxin $\beta$ (OT $\beta)$ (220), which are OTA analogues, were also found in some $A$. niger strains. ${ }^{118,119}$ Ochratoxin $\alpha$ (219) was reported as a degradation product of the fungus when OTA was treated with its crude enzymes. This compound did not exert cytotoxic effect on cell metabolism, probably due to

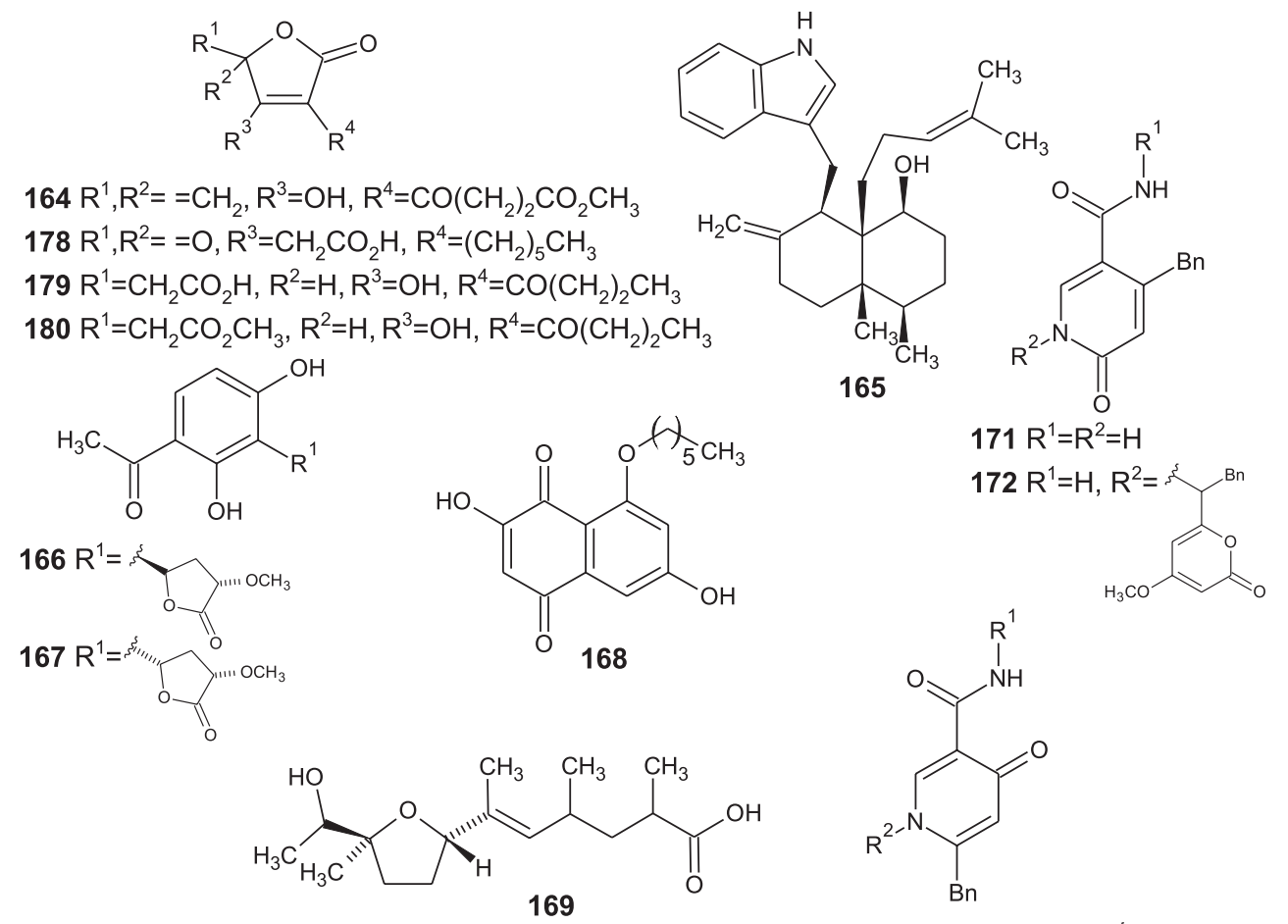

<smiles>O=C1C(O)=C(c2ccc(O)cc2)C(=O)C(O)=C1c1ccc(O)cc1</smiles><smiles>[R]C1CC[C@]2(C)Oc3cc4c(c(O)c3[C@@H]1O2)C(=O)c1c(O)cc(O)cc1C4=O</smiles>

$176 \mathrm{R}^{1}=\mathrm{H}$

$199 \mathrm{R}^{1}=\mathrm{OH}$<smiles>COC(=O)c1cc2ccoc2cc1C=O</smiles>

177<smiles>CO[C@H]1C(=O)CC[C@@](O)(CCl)[C@@]1(O)C1(C)O[C@@H]1CC=C(C)C</smiles>

181<smiles>COC(=O)c1ccc(C(Cc2ccccc2)NC(C)=O)o1</smiles>

184

Figure 15. Chemical structures of miscellaneous compounds (164-213) produced by A. niger strains. 
<smiles>COC1=C(O)c2c(O)cc(C)c3c(O)cc(O)c(c23)C1=O</smiles>

183<smiles>C=C1OC(=O)C(=C2CCCO2)C1=O</smiles>

185<smiles>[R]c1c([R])c([R])c(C)c([R])c1[R]</smiles>

$182 \mathrm{R}^{1}=\mathrm{CHO}, \mathrm{R}^{2}=\mathrm{R}^{4}=\mathrm{OH}, \mathrm{R}^{3}=\mathrm{CH}_{3}, \mathrm{R}^{5}=\mathrm{H}, \mathrm{R}^{6}=$

$190 \mathrm{R}^{1}=\mathrm{R}^{3}=\mathrm{R}^{4}=\mathrm{R}^{6}=\mathrm{H}, \mathrm{R}^{2}=\mathrm{CH}_{2} \mathrm{CO}_{2} \mathrm{H}, \mathrm{R}^{5}=\mathrm{OH}$

$192 R^{1}=R^{3}=R^{4}=R^{6}=H, R^{2}=C_{2} C O_{2} H, R^{5}=O_{3}$

$193 R^{1}=R^{3}=R^{4}=R^{5}=R^{6}=H, R^{2}=$ OH

$196 \mathrm{R}^{1}=\mathrm{OH}, \mathrm{R}^{2}=\mathrm{R}^{3}=\mathrm{R}^{5}=\mathrm{R}^{6}=\mathrm{H}, \mathrm{R}^{4}=\mathrm{CH}_{3} \mathrm{CH}_{3} \mathrm{O}^{-\mathrm{CH}_{3}}$

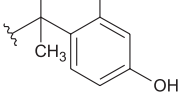

$202 \mathrm{R}^{1}=\mathrm{CONH}_{2}, \mathrm{R}^{2}=\mathrm{CO}_{2} \mathrm{H}, \mathrm{R}^{3}=\mathrm{OCH}_{3}, \mathrm{R}^{4}=\mathrm{CH}_{3}, \mathrm{R}^{5}=\mathrm{CHCHCH}_{3}, \mathrm{R}^{6}=\mathrm{OH}$

$207 \mathrm{R}^{1}=\mathrm{R}^{3}=\mathrm{R}^{4}=\mathrm{R}^{5}=\mathrm{R}^{6}=\mathrm{H}, \mathrm{R}^{2}=\mathrm{OCH}_{2} \mathrm{CO}_{2} \mathrm{H}$

$208 R^{1}=R^{3}=R^{4}=R^{5}=R^{6}=H, R^{2}=C_{2} C_{2} \mathrm{H}_{2}$

$209 \mathrm{R}^{1}=\mathrm{CH}_{2} \mathrm{CH}_{2} \mathrm{OH}, \mathrm{R}^{2}=\mathrm{R}^{3}=\mathrm{R}^{4}=\mathrm{R}^{5}=\mathrm{R}^{6}=\mathrm{H}$

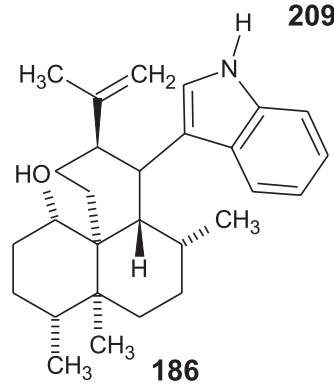<smiles>COC1=C(O)C2(C)CC(=O)Oc3ccccc3CC2C(O)=CC1O</smiles>

188<smiles>CC1=CC(=O)CC(C)(C)[C@H]1CCC(C)O</smiles><smiles>[R]CC([R])C([R])C</smiles>

$189 \mathrm{R}^{1}=\mathrm{CH}_{3}, \mathrm{R}^{2}=\mathrm{R}^{3}=\mathrm{H}, \mathrm{R}^{4}=$ s<smiles>[R]C[Y9]C(C(=C)C(=O)O)C(=O)O</smiles>

$194 \mathrm{R}^{1}=\mathrm{H}$

$195 \mathrm{R}^{1}=\mathrm{OH}$<smiles>O=c1cc(CO)occ1O</smiles>

191<smiles>[R]C=CC(=O)N1C[C@@H](C)N(C)C[C@H]1[Z2]</smiles>

$200 \mathrm{R}^{1}=\mathrm{CH}_{3}(\mathrm{eq}), \mathrm{R}^{2}=\mathrm{Ph}$

$201 \mathrm{R}^{1}=\mathrm{CH}_{3}(\mathrm{ax}), \mathrm{R}^{2}=\mathrm{Ph}$

$203 \mathrm{R}^{1}=\mathrm{CH}_{3}(\mathrm{ax}), \mathrm{R}^{2}=\mathrm{CHCHCH}_{3}$<smiles>[R]C(O)[C@H]1O[C@]2(C(=O)N[C@@](OC)(C(=O)c3ccccc3)[C@@H]2O)C(=O)C1C</smiles>

$$
\overbrace{\mathrm{OH}}
$$

$197 \mathrm{R}^{1}=\mathrm{CH}_{3}, \mathrm{R}^{2}=\mathrm{OH}, \mathrm{R}^{3}=\mathrm{H}, \mathrm{R}^{4}=\mathrm{s}$

$198 \mathrm{R}^{1}=\mathrm{R}^{3}=\mathrm{H}, \mathrm{R}^{2}=\mathrm{CH}_{3}, \mathrm{R}^{4}=\mathrm{OH}$

$204 \mathrm{R}^{1}=\mathrm{CH}_{3}, \mathrm{R}^{2}=\mathrm{R}^{3}=\mathrm{H}, \mathrm{R}^{4}=\xi \mathrm{CH}_{\mathrm{CH}_{2}}^{\mathrm{OH}}$<smiles>C=C1C(=O)C1O</smiles><smiles>[R]Oc1cn(Cc2ccccc2)c2occ(O)c12</smiles>

$205 \mathrm{R}^{1}=\mathrm{CH}_{3}, \mathrm{R}^{2}=\mathrm{R}^{3}=\mathrm{H}, \mathrm{R}^{4}=$ 党 $\mathrm{CH}_{2}$<smiles>[R2][R]([R4])C(=[R4])C(=O)CC(C)C(=O)O</smiles>

Figure 15. Chemical structures of miscellaneous compounds (164-213) produced by A. niger strains (cont.). 
Table 12. Miscellaneous (164-213) produced by A. niger strains

\begin{tabular}{|c|c|c|c|}
\hline Compound & Strain & Source & Reference \\
\hline Agglomerin F (164) & ATCC 1015 & $\mathrm{nr}$ & 94 \\
\hline Anominine (165) & IBT 29019 & endophyte & 74 \\
\hline Antafumicin A (166) & NH-401 & $\mathrm{nr}$ & 95 \\
\hline $\begin{array}{l}\text { Antafumicin B (167) } \\
\text { Asperaldin }(\mathbf{1 6 8})\end{array}$ & CFR-1046 & $\mathrm{nr}$ & 96 \\
\hline Asperic acid (169) & UCSC 94-1212 & marine & 51 \\
\hline Aspernigerin (170) & IFB E003 & endophyte & 97 \\
\hline Aspernigrin A (171) & $\begin{array}{l}\text { CBX } 1462002 \\
\text { SCSIO Jcsw6F30 }\end{array}$ & $\begin{array}{l}\text { marine } \\
\text { marine }\end{array}$ & $\begin{array}{l}70 \\
41\end{array}$ \\
\hline \multirow[t]{2}{*}{ Aspernigrin B (172) } & CBX 1462002 & marine & 70 \\
\hline & SCSIO Jcsw6F30 & marine & 41 \\
\hline Aspernigrin C (173) & SCSIO Jcsw6F30 & marine & 41 \\
\hline Aspernigrin D (174) & SCSIO Jcsw6F30 & marine & 41 \\
\hline Atromentin (175) & LL-LV 3020 & marine & 69 \\
\hline Averufin (176) & MF 16 & marine & 93 \\
\hline 5-Benzofuran carboxylic acid-6-formyl methyl ester (177) & $\mathrm{nr}$ & endophyte & 98 \\
\hline 2-Carboxymethyl-3-hexylmaleic acid anhydride (178) & A. niger 5 No. 22 & $\mathrm{nr}$ & 99 \\
\hline Carlosic acid (179) & ATCC 1015 & $\mathrm{nr}$ & 94 \\
\hline \multicolumn{4}{|l|}{ Carlosic acid methyl ether (180) } \\
\hline Chlovalicin (181) & BRF 074 & marine & 57 \\
\hline FK17-P2a (182) & ATCC 1015 & mutant strain & 84 \\
\hline Funalenone (183) & FO 5904 & soil & 100 \\
\hline Furan ester derivative (184) & BRF 074 & marine & 57 \\
\hline Dihydrocarolic acid (185) & AM 410 & soil & 101 \\
\hline 10,23-Dihydro-24,25-dehydroaflavinine (186) & IBT 29019 & endophyte & 42 \\
\hline 4-(3'(R)-Hydroxybutyl)-3,5,5, trimethyl-cyclohex-2-en-1-one (187) & $\mathrm{nr}$ & endophyte & 98 \\
\hline $\begin{array}{l}\text { 8,10,12-Trihydroxy-9-methoxy-7 } \alpha \text {-methyl-7,7 } \alpha, 12 \alpha, 13 \text {-tetrahydrobenzocycloheptaoxocin- } \\
\text { 6-one (188) }\end{array}$ & $\mathrm{nr}$ & endophyte & 102 \\
\hline 5,8-Dihydroxy-9-octadecenoic acid (189) & КСCM 60318 & $\mathrm{nr}$ & 103 \\
\hline $\begin{array}{l}p \text {-Hydroxyphenylacetic acid (190) } \\
\text { Kojic acid (191) }\end{array}$ & AKRN & endophyte & 43 \\
\hline p-Methoxyphenylacetic acid (192) & $\mathrm{nr}$ & endophyte & 104 \\
\hline Methyl (Z)-4-\{[(Z)-1-(hydroxymethyl)-2-phenyl-1-ethenyl] amino $\}$-4-oxo-2-butenoate (193) & Ta 1 & $\mathrm{nr}$ & 105 \\
\hline $\begin{array}{l}\text { 2-Methylene-3-hexyl-butanedioic acid (194) } \\
\text { 2-Methylene-3-(6-hydroxyhexyl)-butanedioic acid (195) }\end{array}$ & A. niger 5 No. 22 & $\mathrm{nr}$ & 99 \\
\hline 2-(2'-Methyl,4'-hydroxyphenyl)2-(4”'-hydroxyphenyl)-propane (196) & CFTRI 1105 & $\mathrm{nr}$ & 106 \\
\hline Methyl 3-methyl-8-hydroxy-4-decenoate (197) & $\mathrm{nr}$ & endophyte & 104 \\
\hline 2-Methylpropan-1-ol (198) & $\mathrm{nr}$ & $\mathrm{nr}$ & 107 \\
\hline Nidurufin (199) & MF 16 & marine & 93 \\
\hline $\begin{array}{l}\text { Nigerazine A (200) } \\
\text { Nigerazine B (201) }\end{array}$ & I 639 & soil & 108 \\
\hline Nigerloxin (202) & CFR-W 105 & $\mathrm{nr}$ & 109,110 \\
\hline Nigragillin (203) & IBT 29019 & endophyte & 42 \\
\hline 1-Octen-3-ol (204) & $\mathrm{nr}$ & $\mathrm{nr}$ & 107 \\
\hline 1-Octen-3-one (205) & $\mathrm{AB} 1.13$ & $\mathrm{nr}$ & 81 \\
\hline Penitricin D (206) & AM 410 & soil & 101 \\
\hline $\begin{array}{l}\text { Phenoxyacetic acid (207) } \\
\text { Phenylacetic acid (208) }\end{array}$ & $\mathrm{nr}$ & endophyte & 104 \\
\hline 2-Phenylethanol (209) & $\begin{array}{c}\mathrm{nr} \\
\text { JUBT } 3 \mathrm{M}\end{array}$ & $\begin{array}{l}\text { endophyte } \\
\text { endophyte }\end{array}$ & $\begin{array}{l}104 \\
111\end{array}$ \\
\hline $\begin{array}{l}\text { Pseurotin A (210) } \\
\text { Pseurotin D (211) }\end{array}$ & BRF 074 & marine & 57 \\
\hline Tensidol A (212) & FKI 2342 & soil & 112 \\
\hline Tensidol B (213) & $\begin{array}{l}\text { IBT } 29019 \\
\text { FKI } 2342\end{array}$ & $\begin{array}{l}\text { endophyte } \\
\text { soil }\end{array}$ & $\begin{array}{c}42 \\
112 \\
\end{array}$ \\
\hline
\end{tabular}

nr: not reported; FK17-P2a: 2,4-dihydroxy-6-(4-hydroxy-2-oxopentyl)-3-methylbenzaldehyde. 
<smiles>[R]C(=O)c1cc([R])c2c(c1O)C(=O)O[C@H](C)C2</smiles>

Figure 16. Chemical structures of mycotoxins (214-220) produced by A. niger strains.

Table 13. Mycotoxins (214-220) produced by A. niger strains

\begin{tabular}{lccc}
\hline Compound & Strain & Source & Reference \\
\hline Fumonisin B2 (214) & $\mathrm{nr}$ & endophyte & 114 \\
& NRRL 326 & $\mathrm{nr}$ & 115 \\
& NRRL 3122 & mutant strain & 116 \\
& $\mathrm{nr}$ & endophyte & 66 \\
Fumonisin B4 (215) & $\mathrm{nr}$ & endophyte & 114 \\
Fumonisin B6 (216) & NRRL 326 & $\mathrm{nr}$ & 115 \\
Gliotoxin (217) & $\mathrm{nr}$ & $\mathrm{nr}$ & 117 \\
Ochratoxin A (218) & $\mathrm{nr}$ & endophyte & 66 \\
Ochratoxin $\alpha(\mathbf{2 1 9})$ & IBT 28144 & $\mathrm{nr}$ & 118 \\
Ochratoxin $\beta$ (220) & $\mathrm{nr}$ & $\mathrm{nr}$ & 119 \\
\hline
\end{tabular}

nr: not reported.

its more lipophilic nature when compared to OTA that has the hydrophilic L- $\beta$-phenylalanine group. ${ }^{128}$ The capacity of A. niger 1062 to biosynthesize OTA, OT $\alpha$ and OT $\beta$ was removed through the disruption of its polyketide synthase gene An15g07920. ${ }^{129}$ Gliotoxin (217) is a redox-active metabolite which inhibited the growth of other fungi and was found in A. niger strains from cancer patients. ${ }^{17}$

Despite BNPs have been reported as vertebral central nervous toxins, they cannot be regarded as mycotoxins because they were not shown to be toxic when administered by a natural route but rather after intraperitoneal injection. ${ }^{37}$ Although malformin C (92, Figure 5) has been often referred as toxin, in this review it was allocated in the cyclopeptide class, since this compound is not considered mycotoxin by the Council of Agricultural Science and Technology (CAST). ${ }^{130}$

\section{Biotransformation of Terpenes by A. niger Strains}

Microbial-mediated transformations of organic compounds, including natural products, have been used as an important strategy for producing new bioactive compounds through chemo-, regio- and/or stereoselective reactions. In this field, many fungi species have been revealed as promising biocatalysts, being able to promote chemical modifications that are difficult to reproduce under conventional catalysis. ${ }^{131,132} \mathrm{~A}$. niger has been considered a cell factory of enzymes of industrial interest ${ }^{133}$ and it is highlighted as an adaptable species for laboratory and industrial-scale microbial transformations.

The use of strains of this fungus on the biotransformation of organic compounds, ${ }^{23}$ steroids and flavonoids ${ }^{22}$ besides terpenoids ${ }^{24}$ was reviewed in the literature. In the latter revision ${ }^{24}$ (literature covered from 1960 to 2013), the authors present various examples of the use of A. niger strains that promoted stereoselective biotransformation in terpenoids to yield compounds of industrial interest to flavors, fragrances or pharmaceutical industries.

The first biotransformation of a terpene by A. niger was reported by Bhattacharyya et al..$^{134}$ (1960) on the study of microbiological hydroxylation of the monoterpene (+)- $\alpha$-pinene. Since then, about 121 terpenoids (36 mono-, 52 sesqui-, 31 di- and 2 triterpenes) were biotransformed by various strains of $A$. niger, revealing the ability of this fungus to mediate different enzymatic reactions on the presence of the natural product and/or its derivative.

The microbial transformations reported to this class of compounds, although not unique to this species, are 
extremally diverse. In general, the $\mathrm{Csp}^{3}$ oxidation ${ }^{24,135-147}$ is the most widespread reaction that occurs in various structural types of terpenoids, including monoterpenes, diterpenes and sesquiterpenes. Some examples of $\mathrm{Csp}^{2}$ oxidation, ${ }^{24,142,147-150}$ $\mathrm{C}=\mathrm{C}$ dihydroxylation, ${ }^{24} \mathrm{C}=\mathrm{C}$ reduction, ${ }^{24,150} \mathrm{C}=\mathrm{C}$ migration,,${ }^{24,145,150} \mathrm{C}=\mathrm{O}$ reduction, ${ }^{24,150}$ hydrolyses, ${ }^{24}$ epoxide opening,,$^{24,135,150}$ ring opening, ${ }^{24,139,149}$ elimination, ${ }^{24,135,148,150}$ $\mathrm{OH}$ oxidation, ${ }^{24,135,150}$ acetylation, ${ }^{24}$ heterocyclization, ${ }^{24}$ dehydrogenation, ${ }^{24}$ esterification, ${ }^{24,142,145}$ oxidative ring opening, ${ }^{24}$ Baeyer-Villiger, ${ }^{146,148}$ demethylation, ${ }^{136}$ Michael addition, ${ }^{24}$ peroxide deoxygenation, ${ }^{24} \mathrm{O}$-alkylation, ${ }^{24}$ aromatization, ${ }^{24,139}$ Beckmann rearrangement, ${ }^{146} \mathrm{Csp}^{3}$ halogenation, ${ }^{145} \mathrm{CO}_{2} \mathrm{H}$ reduction (conversion of lactam to $\mathrm{CN}),{ }^{24,145}$ deoxygenation, ${ }^{149}$ lactone isomerization, ${ }^{144}$ lactonization, ${ }^{146}$ oxidative cleavage at side chain, ${ }^{24}$ phenyl oxidation ${ }^{24}$ and spirolactonization ${ }^{24}$ were also reported. However, few examples were found involving biotransformation of triterpenes by A. niger, which were restricted to saponins, and resulted in products from either partial or total hydrolysis of glycoside chains. ${ }^{24}$

Unlike the review from Parshikov and Sutherland, ${ }^{24}$ which presents all examples of biotransformation of the terpenoids divided by their classes (mono-, sesqui-, di- and triterpenes), this topic will highlight some examples that involved the most uncommon microbial transformations.

Not so frequently mediated by A. niger on biotransformations of terpenes but with great importance to generate new uncommon terpenoids are the BaeyerVilliger (BV), Michael addition, Beckmann rearrangement, spirolactonization and peroxide deoxygenation reactions. Therefore, the examples of these reactions on biotransformations of terpenes by A. niger will be discussed below. Whenever appropriate, some proposed pathways involved on the formation of products will be presented.

The microbial transformation of thymoquinone (221) by suspended cell-cultures of ATCC 16404 strain yielded compound 5-isopropyl-2-methyloxepin-1-one
(222) besides 3-hydroxy-5-isopropyl-2-methylcyclohexa2,5-diene-1,4-dione, and 5-isopropyl-2-methylbenzene1,4-diol (Figure 17). ${ }^{148}$ The proposed pathway for the synthesis of compound (222) suggested that it underwent $\mathrm{BV}$ type oxidation of regioselective $\mathrm{C}=\mathrm{C}$ reduced benzoquinone, followed by reduction of $\mathrm{C}=\mathrm{O}$ bond and elimination of water.

Baeyer-Villiger reaction was also observed on the microbial transformation of isosteviol oxime derivative (223) using BCRC 32720 strain, that yield isosteviol lactone (4R-carboxy-13R-hydroxy-13,16-seco-ent-19-norbeyeran16-oic acid 13,16-lactone, 224), besides products coming from abnormal Beckmann rearrangement (225 and 226), and the isosteviol lactam ( $4 R$-carboxy-13R-amino13,16-seco-ent-19-norbeyeran-16-oic acid 13,16-lactam, 227) from Beckmann rearrangement (Figure 18). ${ }^{146}$ It is worth note that this was the first report of these products formation by microbial catalysis.

The production of these compounds can be justified by the sequence of reactions displayed at Figure 19. ${ }^{151}$ The first step involves the formation of carbocations ( 228 and 229) as intermediates for the next steps. The regioisomeric compounds (225 and 226) are formed by $\alpha$-proton elimination in the nitrile carbocation (228, path a), which were considered an abnormal Beckmann rearrangement. ${ }^{146}$ Addition of water to this carbocation yields the unstable imidate (230), which easily hydrolyses to lactone (224, path b). Lactam (227) is formed through Beckmann rearrangement after water addition to carbocation (229, path c).

Chang and co-workers ${ }^{144}$ also obtained isosteviol lactone (224) by derivatization of isosteviol (ent-16-oxobeyeran19-oic acid, 231) with $m$-chloroperbenzoic acid and submitted this compound to biotransformation by A. niger BCRC 32720 strain. Some products from regio- and stereoselective hydroxylation were formed besides a new lactone (4R-carboxy-15R-hydroxy-15,16-seco-ent-

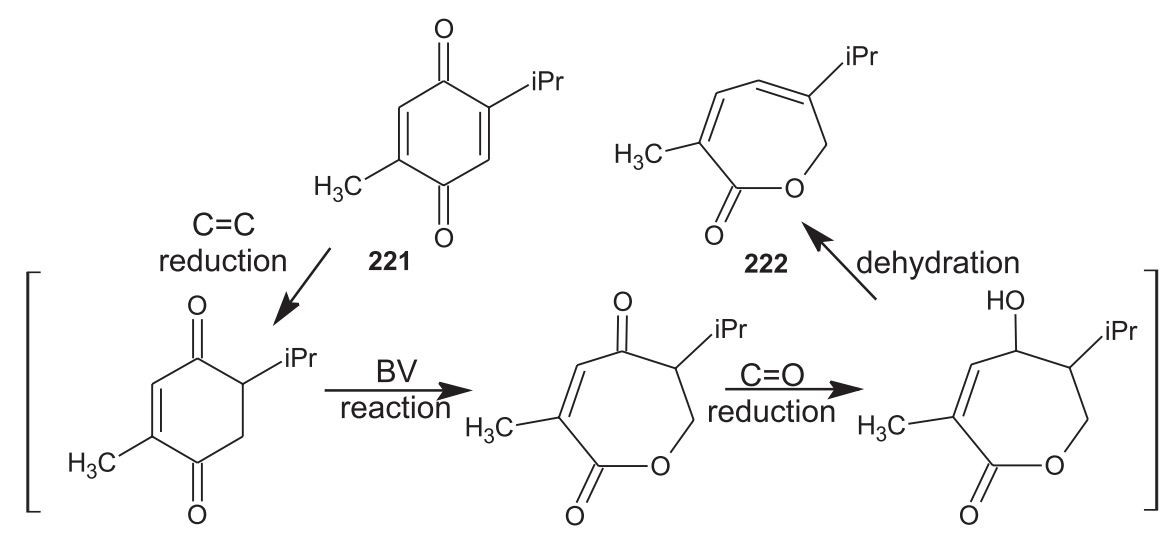

Figure 17. Proposed pathway for production of compound 222 through biotransformation of thymoquinone (221) by A. niger ATCC 16404. 


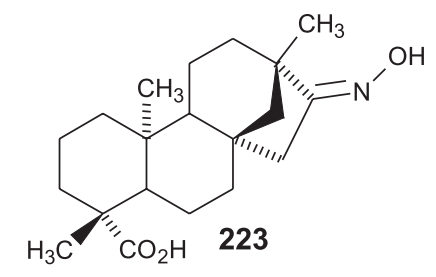

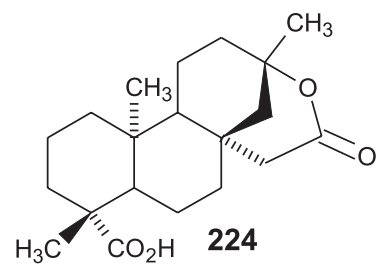

<smiles>CCCC[C@]12CC(=O)N[C@](C)(CCC1[C@]1(C)CCC[C@@](C)(C(=O)O)C1CC)C2</smiles>

Figure 18. Chemical structures of isosteviol oxime (223) and its biotransformation products 224-227 by A. niger BCRC 32720.<smiles>CC[C@H]1CCC2(C)C[C@]1(CC)CC2=N</smiles>



Figure 19. Proposed pathway for production of compounds 224-227 through biotransformation of isosteviol oxime (223) by A. niger BCRC 32720 .

19-norbeyeran-16-oic acid 15,16-lactone, 232) coming from the unexpected isomerization of the lactone ring, and its $1 \alpha, 7 \beta$-hydroxylated derivatives (Figure 20).

Transformation of steviol lactam (227) by the same strain involved diverse reactions. Chlorination reactions occurred at C-15 from lactam (227) and at C-12 from compound (234) (Figure 21). ${ }^{145}$ The mechanism to produce both chlorinated compounds ( 233 and $\mathbf{2 3 4}$ ) is not clear, but the authors ${ }^{145}$ suggested that it may involve the action of chloroperoxidases, and that the chlorine atom was probably derived from the addition of $\mathrm{NaCl}$ to the fermentation medium.

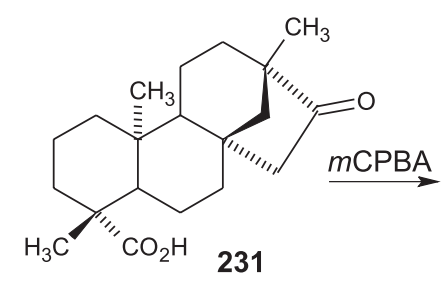

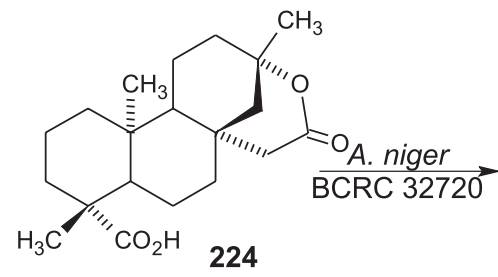

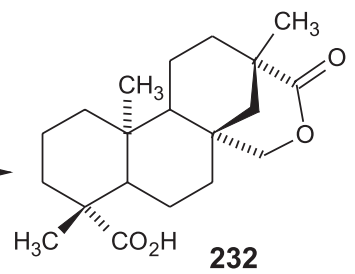

Figure 20. Chemical preparation of isosteviol lactone (224) from isosteviol (231) and biotransformation of $\mathbf{2 2 4}$ by A. niger BCRC 32720 to produce compound 232. 




Figure 21. Chemical structures of steviol lactam (227) and its biotransformation products $\mathbf{2 3 3}$ and $\mathbf{2 3 4}$ by A. niger BCRC 32720 .

The microbial transformation of the sesquiterpene endoperoxide artemisitene (235) by NRRL 599 strain revealed, among double bond hydrogenation products, the unusual $9 \beta$-hydroxydeoxy-11-epi-artemisinin (236) compound, obtained by the reduction of the peroxide linkage (Figure 22). ${ }^{152}$ However, a similar transformation happened when the analogue artemisinin was investigated as substrate to be biotransformed by A. niger AS 3.1858. ${ }^{153}$ In this case, the authors ${ }^{153}$ also found the deoxy product in the substrate control, without any microorganisms, indicating that it may be an artifact produced by chemical reaction catalyzed by $\mathrm{Fe}^{+2}$ in potato medium.

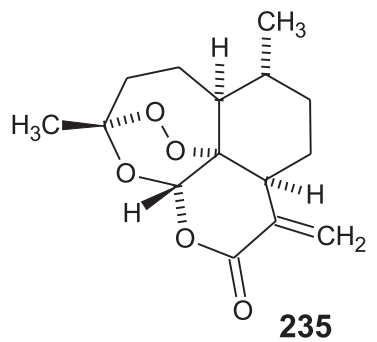<smiles>CC1C(=O)O[C@H]2O[C@]3(C)CC[C@@H]1[C@H](C)[C@H](O)C[C@H]2O3</smiles>

Figure 22. Chemical structures of artemisitene (235) and its biotransformation product 236 by A. niger NRRL 599.
Artemisinin (237) was also biotransformed by VKM F-1119 strain to produce the new products $3 \beta$-hydroxy-4,12-epoxy-1-deoxyartemisinin (238), 3,13-epoxyartemisinin (239) and $4 \alpha$-hydroxy1-deoxyartemisinin (240), which display epoxy structures, besides the ring rearranged product artemisinin $G(\mathbf{2 4 1})$ (Figure 23). ${ }^{149}$ Despite the existence of some studies of microbial transformation of artemisinin and derivatives, it was the first report of epoxidation and rearrangement of artemisinin using microbial strains.

$\alpha, \beta$ and $\gamma$-cyclocostunolide sesquiterpenes (242-244), obtained easily by treatment of costunolide with thionyl chloride in $\mathrm{CHCl}_{3}$, were biotransformed by A. niger to give new derivatives. ${ }^{154}$ Among them, it is highlighted the formation of the sulfide compounds (245 and 246, from $\alpha$ - and $\beta$-cyclocostunolides, respectively) through either Michael addition at $\mathbf{2 4 2}$ and $\mathbf{2 4 3}$ or nucleophilic substitution at $\mathrm{C} 13$ of compounds $\mathbf{2 4 7}$ and $\mathbf{2 4 8}$ (Figure 24). In both cases, compound ethyl 2-hydroxy-3-mercaptopropanate is the nucleophile which might be originated from Czapekpeptone medium. It is noteworthy that no sulfide product was detected on biotransformation of the $\gamma$-isomer. As far as we know, this is the first example of 3-mercaptopropanate products from terpene biotransformations by A. niger.

The same Michael addition reaction occurred when $7 \alpha$-hydroxyfrullanolide (249) was incubated with A. niger ATCC 1004 strain, which yielded the acetylated compound (250) (Figure 25), besides oxidized derivatives. ${ }^{155}$ This result was considered a novel "umpolung-type" microbial reaction.

Curdione (251) was biotransformed by AS 3739 strain to yield new compounds. Among them, it is worth highlighting those bearing a spirolactone skeleton (252-255), Figure $26 .{ }^{156}$ The spirolactonization of curdione<smiles>C[C@H]1CC[C@H]2[C@@H](C)C(=O)O[C@H]3O[C@]4(C)CC[C@@H]1[C@@]23OO4</smiles>

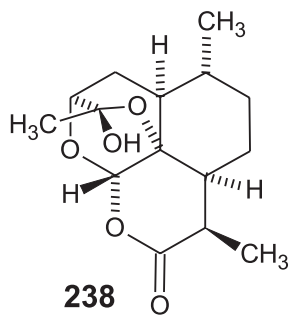<smiles>C[C@H]1CC[C@H]2[C@@H](C)C(=O)O[C@H](O)[C@@]23CC[C@H]1[C@]1(CO1)OO3</smiles>

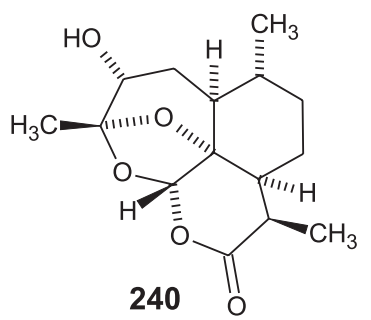<smiles>[Z14]O[C@H]1OC(=O)[C@H](C)[C@@]23CCC[C@H](C)[C@H]2CCO[C@]13[C@@H](C)OC(C)=O</smiles>

Figure 23. Chemical structures of artemisinin (237) and its biotransformation products 238-241 by A. niger VKM F-1119. 

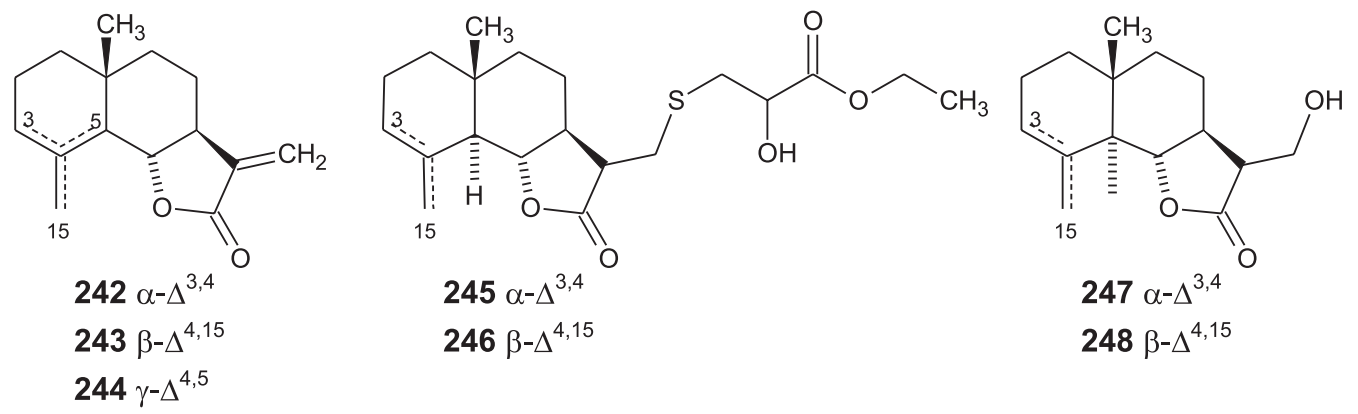

Figure 24. Chemical structures of $\alpha, \beta$ and $\gamma$-cyclocostunolides (242-244) and their biotransformation products 245-248 by A. niger.<smiles>[R4]O[C@]12CC[C@@]3(C)CCCC(C)=C3[C@@]1(C)CC2=O</smiles><smiles>CC(=O)C[C@H]1C(=O)O[C@]2(C)C1=C(C)CCCC2(C)C</smiles>

Figure 25. Chemical structures of $7 \alpha$-hydroxyfrullanolide (249) and its biotransformation product 250 by A. niger ATCC 1004 .

was previously reported from chemical transformation of this compound with catalytic amounts of $\mathrm{HCl}$ in chloroform. ${ }^{157}$ The reaction happened via intramolecular ene-reaction which was considered a rearrangement catalyzed by acid. This result contributed to the proposition of the biogenetic pathway depicted in Figure 26, which agrees with the fact that $A$. niger cultured in nutrient medium excretes large amounts of acid. ${ }^{156}$

The microbial transformation of (-)- $\alpha$-santonin (256) was carried out by A. niger M1L 5024 strain in the presence of $\alpha, \alpha^{\prime}$-dipyridyl to yield the new B-ring opened aromatic compounds, 3,6,9-trihydroxy-9,10-seco- selina-1,3,5(10)-trien-12-oic acid 12,6-1actone (257) and 3,6-dihydroxy-9,10-seco-selina-1,3,5(10)-trien-9,12-dioic acid 12,6-1actone (258) (Figure 27), besides a hydroxylated product at C-11. ${ }^{139}$ The authors suggested that the formation of these products might involve the microbial formation of a postulated 9-hydroxylated intermediate (259), that spontaneously undergoes reverse aldol reaction as represented in Figure 27. It is noteworthy that the breakdown of the B-ring accompanied by aromatization of the A-ring was previously reported from microbial transformation of steroids. ${ }^{158}$

Biotransformation of stypotriol acetate (260) by ATCC 16404 yielded 6',14-diacetoxy-stypol-4,5-dione (261), which bears a 1,2-benzoquinone moiety instead of the initial aromatic ring (Figure 28). ${ }^{159}$ The authors suggested the initial formation of intermediates 262 and 263 through deacetylation reaction catalyzed by esterases followed by oxidation of the aromatic ring. Finally, the product $\mathbf{2 6 1}$ was formed through rapid air oxidation of intermediate $\mathbf{2 6 3}$ during the course of its isolation, as previously observed by Gerwick and Fenical ${ }^{160}$ (1981) in the isolation of stypoldione.

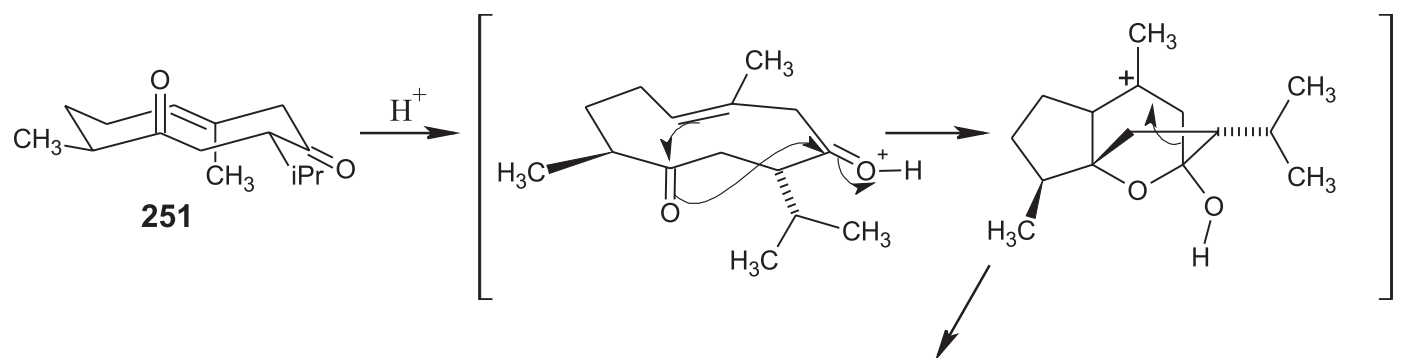<smiles>CC(C)[C@H]1C[C@@]2(OC1=O)C([C@@](C)(O)CO)CC[C@@H]2C</smiles>

$254 \alpha \mathrm{OH}$

$255 \beta \mathrm{OH}$<smiles>[R1][C@@H]1C[C@H](C(=C)C)[C@@]2(C[C@@H](C(C)C)C(=O)O2)[C@H]1C</smiles>

$252 \mathrm{R}^{1}=\mathrm{H}$

$253 \mathrm{R}^{1}=\mathrm{OH}$

Figure 26. Proposed pathway for production of compounds 252-255 through biotransformation of curdione (251) by A. niger AS 3739 . 


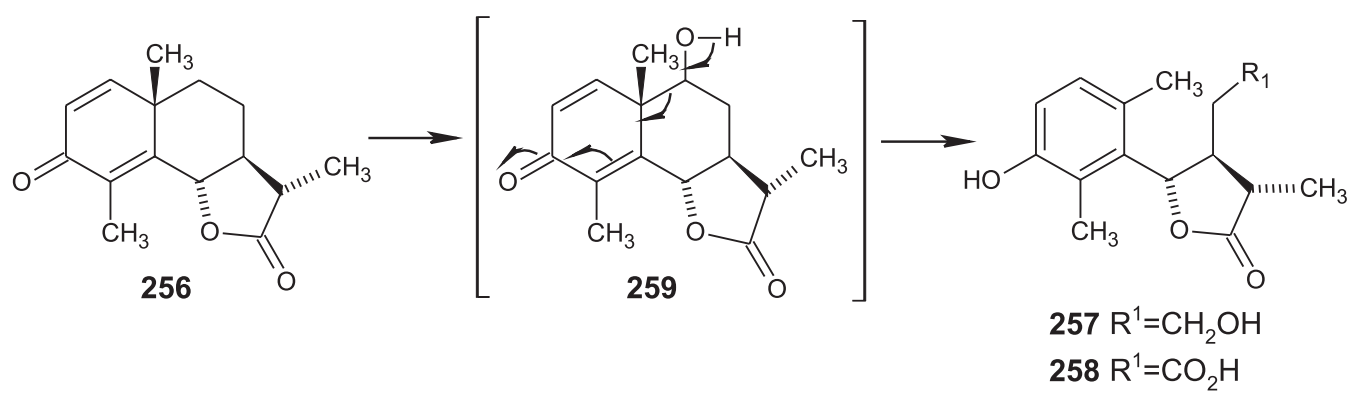

Figure 27. Proposed pathway for production of compounds 257 and 258 through biotransformation of (-)- $\alpha$-santonin (256) by A. niger M1L 5024 in the presence of $\alpha, \alpha$ '-dipyridyl.

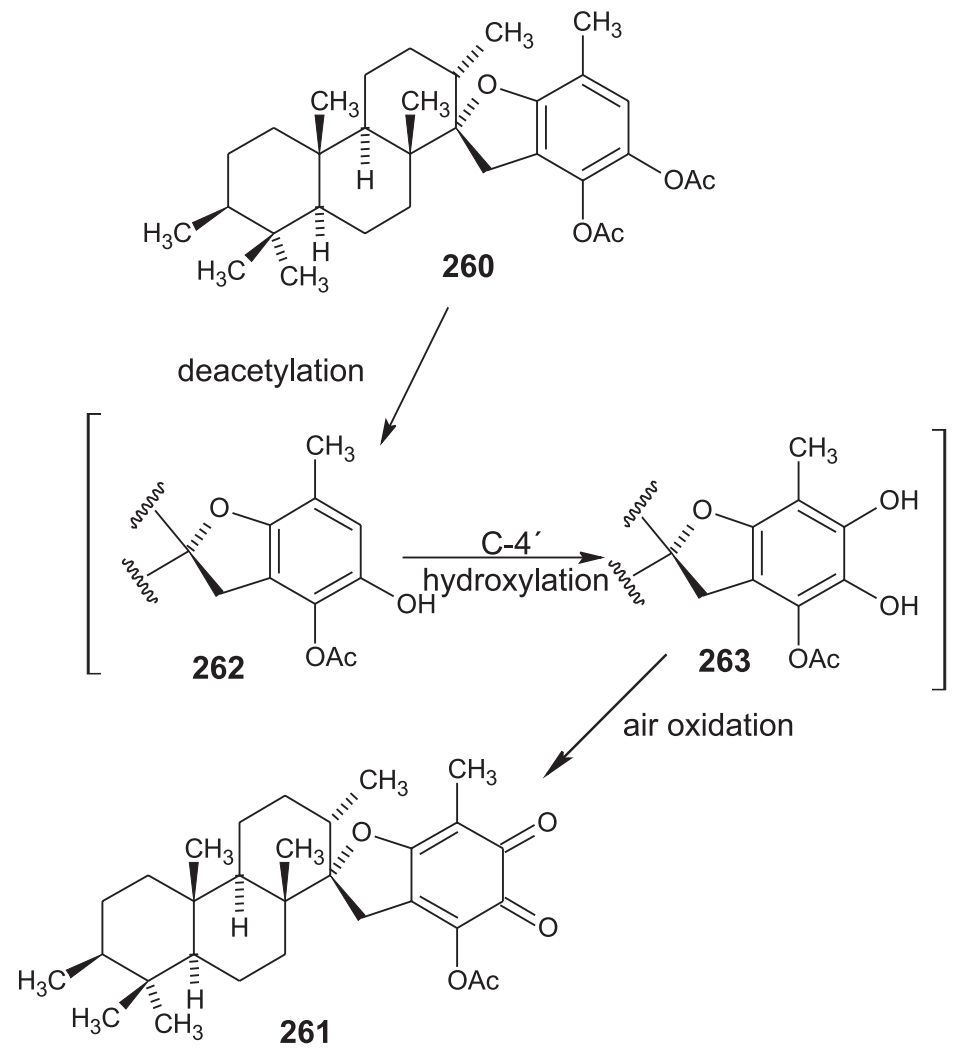

Figure 28. Proposed pathway for production of compound 261 through biotransformation of stypotriol acetate (260) by A. niger ATCC 16404.

Platycodin D (264) is a saponin bearing a 3-O-glucose and a 28-O-apiose-xylose-rhamnose-arabinose. The microbial transformation of this natural product by $A$. niger KCTC 6906 strain yielded the novel partially degraded platycodin glycoside (265) (Figure 29). ${ }^{161}$ The cleavage of the sugar at C28 most likely occurred between xylose and rhamnose, resulting in the shorter disaccharide (265), lacking the apiose-xylose portion. It is worth mentioning that this was the first example of selective inner-glycosidic bond cleavage by crude microbial enzymes.

\section{Conclusion and Future Perspectives}

The fundamental and applied scientific investigations of $A$. niger over the last 100 years in the natural product area are extremely diverse. As herein presented, this microorganism was shown as a powerful platform to the biosynthesis of diverse structural classes of compounds, many of them displaying biological properties. In addition, a variety of enzymes from the fungus exhibited regio- and stereoselectivity catalytic activities on biotransformation of natural compounds, yielding unusual derivatives and being considered an alternative to chemical methods. Therefore, the biotechnological potential of A. niger highlights this fungus as one of the most important microorganisms for the production of molecules and enzymes of scientific and industrial interest.

The investigation of this fungus and its congeners along those years also brought significant progress to important areas, including taxonomy, genomics, genetics 


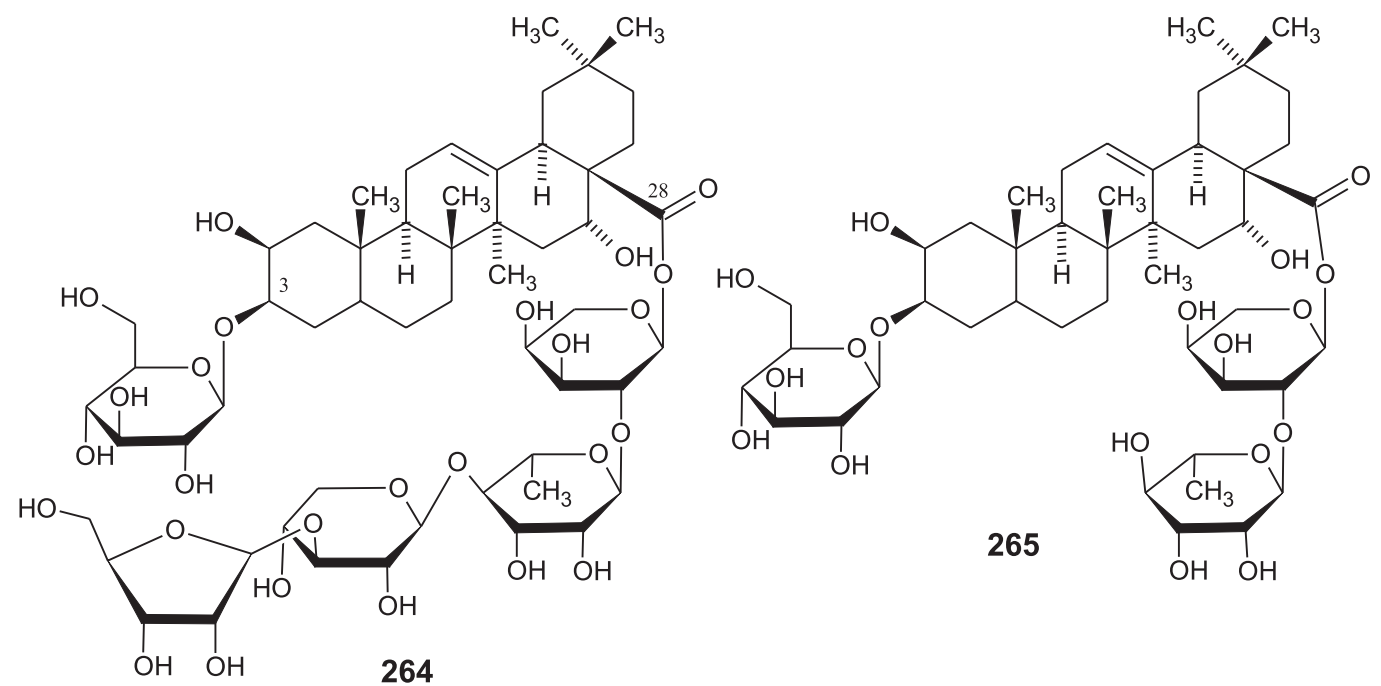

Figure 29. Chemical structures of platycodin D (264) and its partially degraded product $\mathbf{2 6 5}$ by A. niger KCTC 6906.

and molecular biology. In this latter area, considerable developments occurred in the last decades, allowing gene editing to produce new secondary metabolites. ${ }^{162}$ Additionally, this fungus was used as heterologous host microorganism for expressing important enzymes of industrial interest. ${ }^{162-164}$

As previously reported by Sanchez et al., ${ }^{162}$ investigation on Aspergillus genomes revealed that this genus has potential to produce many more secondary metabolites than those reported so far. In the "omics" era, metabolomics has been considered a powerful strategy for the discovery of natural products, and much progress has been achieved on the investigation of secondary metabolites from fungi. ${ }^{165}$ Nevertheless, few examples of the use of metabolomics to assess the metabolite profile of Aspergillus strains were found in the literature ${ }^{166,167}$ and none of them involved A. niger. It is also worth mentioning that despite considerable progress in strategies for waking silenced genes from microorganisms, such as the use of small molecules (epigenetic chemicals) to manipulate the fungal epigenome, few are the examples with $A$. niger and congeners. ${ }^{168}$ Additionally, the strategic use of A. niger in co-culture approach for producing new compounds lacks more investigative works. ${ }^{169}$ Vadlapudi et al. ${ }^{170}$ reported the development of the Aspergillus Secondary Metabolites Database (A2MDB), which contains information on Aspergillus and its secondary metabolome. Among the compounds included in this database, 90 of them were exclusively from A. niger. Thus, A2MDB will be of great importance in the future investigations on $A$. niger metabolites.

Despite the relevant results found along the years on researches with A. niger, that directly contributed to the natural products area, much more progress is expected to be done in the next years with the rapid technological advance on this research field. Therefore, it is presumed that the discovery of still unexpressed genes by A. niger continues to be a challenge on the production of new compounds and enzymes.

\section{Acknowledgments}

The authors thank CNPq for the research fellowships of M. A. S. L. (process 302804/2015-3) and M. C. F. O. (process 307667/2017-0).

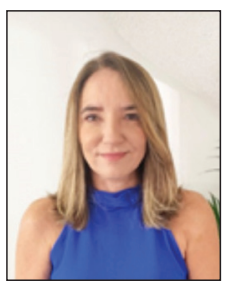

Mary Anne Sousa Lima is Titular Professor at Departamento de Química Orgânica e Inorgânica from Universidade Federal do Ceará (UFC), Ceará State, Brazil. She obtained her undergraduate degree in Chemistry at the Universidade Federal do Ceará, Brazil (1991), the Master's degree in Organic Chemistry at the Universidade Federal do Ceará, Brazil (1991-1993), PhD in Organic Chemistry at the Universidade Estadual de Campinas (UNICAMP), São Paulo State, Brazil (1995-1999), and the postdoctoral at the University of Florida, FL, USA (2015). Her scientific interests include the chemistry of plants and microorganisms.



Maria C. F. Oliveira is Titular Professor at Departamento de Química Orgânica e Inorgânica from Universidade Federal do Ceará (UFC, Fortaleza-CE, Brazil). Her Master's degree (1996) was obtained at UFC 
and involved the chemical investigation of plants. She concluded her doctorate (2001) at Universidade Estadual de Campinas (UNICAMP, Campinas-SP, Brazil) in Organic Synthesis. In 2013, she did a post-doctorate at The University of Arizona (Tucson-AZ, USA). Currently, she has worked with Natural Products and Biocatalysis.

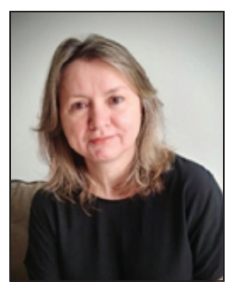

Antônia Torres Ávila Pimenta obtained her undergraduate degree in Pharmacy at Universidade Federal do Ceará (1996), Master (2004) in Organic Chemistry at Universidade Federal do Ceará and concluded the doctorate in Organic Chemistry at Universidade Federal do Ceará (2009). She is currently Adjunct Professor at Departamento de Química Orgânica e Inorgânica from Universidade Federal do Ceará. She has experience in the area of Chemistry of Natural Products, working mainly in the chemical, pharmacy and pharmacological investigation of plants and microorganisms.

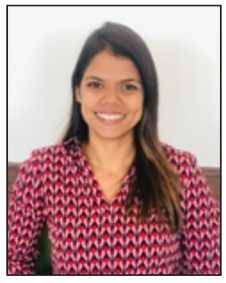

Paula Karina Santos Uchôa is Professor at Instituto Federal de Educação Ciência e Tecnologia do Ceará, Iguatu Campus, Ceará State, Brazil. She obtained her undergraduate degree in Industrial Chemistry at Universidade Federal do Ceará (2009), the Master's degree in Organic Chemistry at Universidade Federal do Ceará (2011) and concluded the doctorate in Organic Chemistry (2017) at Universidade Federal do Ceará, Ceará State, Brazil. Her scientific interests includes the chemistry of natural products of plants and microorganisms.

\section{References}

1. Varga, J.; Frisvad, J. C.; Kocsubé, S.; Brankovics, B.; Szigeti, G.; Samson, R. A.; Stud. Mycol. 2011, 69, 1.

2. Ajav, K.; Gautam, K.; Sharma, S.; Shubhi, A.; Bhadauria, R.; Res. J. Microbiol. 2011, 6, 270.

3. Currie, J. N.; J. Biol. Chem. 1917, 31, 15.

4. Max, B.; Salgado, J. M.; Rodríguez, N.; Cortés, S.; Converti, A.; Domínguez, J. M.; Braz. J. Microbiol. 2010, 41, 862.

5. Tomlinson, N.; Campbell, J. J. R.; Trussell, P. C.; J. Bacteriol. 1951, 61, 17.

6. Kitos, P. A.; Campbell, J. J. R.; Tomlinson, N.; Appl. Microbiol. 1953, 1, 156.

7. Karaffa, L.; Kubicek, C. P.; Appl. Microbiol. Biotechnol. 2003, $61,189$.

8. Papagianni, M.; Biotechnol. Adv. 2007, 25, 244.

9. Baker, S. E.; Med. Mycol. 2006, 44, S17.
10. Pel, H. J.; de Winde, J. H.; Archer, D. B.; Dyer, P. S.; Hofmann, G.; Schaap, P. J.; Turner, G.; de Vries, R. P.; Albang, R.; Albermann, K.; Andersen, M. R.; Bendtsen, J. D.; Benen, J. A. E.; van den Berg, M.; Breestraat, S.; Caddick, M. X.; Contreras, R.; Cornell, M.; Coutinho, P. M.; Danchin, E. G. J.; Debets, A. J. M.; Dekker, P.; van Dijck, P. W. M.; van Dijk, A.; Dijkhuizen, L.; Driessen, A. J. M.; d'Enfert, C.; Geysens, S.; Goosen, C.; Groot, G. S. P.; de Groot, P. W. J.; Guillemette, T.; Henrissat, B.; Herweijer, M.; van den Hombergh, J. P. T. W.; van den Hondel, C. A. M. J. J.; van der Heijden, R. T. J. M.; van der Kaaij, R. M.; Klis, F. M.; Kools, H. J.; Kubicek, C. P.; van Kuyk, P. A.; Lauber, J.; Lu, X.; van der Maarel, M. J. E. C.; Meulenberg, R.; Menke, H.; Mortimer, M. A.; Nielsen, J.; Oliver, S. G.; Olsthoorn, M.; Pal, K.; van Peij, N. N. M. E.; Ram, A. F. J.; Rinas, U.; Roubos, J. A.; Sagt, C. M. J.; Schmoll, M.; Sun, J.; Ussery, D.; Varga, J.; Vervecken, W.; van de Vondervoort, P. J. J.; Wedler, H.; Wösten, H. A. B.; Zeng, A.-P.; van Ooyen, A. J. J.; Visser, J.; Stam, H.; Nat. Biotechnol. 2007, 25, 221.

11. Clarke, A. E.; Stone, B. A.; Biochem. J. 1965, 96, 802.

12. Cain, R. B.; Biochem. J. 1972, 127, 15.

13. Tsuge, H.; Natsuaki, O.; Ohashi, K.; J. Biochem. 1975, 78, 835.

14. Toraya, T.; Fujimura, M.; Ikeda, S.-I.; Fukui, S.; Yamada, H.; Kumagai, H.; Biochim. Biophys. Acta, Protein Struct. 1976, 420, 316.

15. Mill, P. J.; Biochem. J. 1966, 99, 557.

16. Andersen, M. R.; Salazar, M. P.; Schaap, P. J.; Van De Vondervoort, P. J. I.; Culley, D.; Thykaer, J.; Frisvad, J. C.; Nielsen, K. F.; Albang, R.; Albermann, K.; Berka, R. M.; Braus, G. H.; Braus-Stromeyer, S. A.; Corrochano, L. M.; Dai, Z.; van Dijck, P. W.; Hofmann, G.; Lasure, L. L.; Magnuson, J. K.; Menke, H.; Meijer, M.; Meijer, S. L.; Nielsen, J. B.; Nielsen, M. L.; van Ooyen, A. J.; Pel, H. J.; Poulsen, L.; Samson, R. A.; Stam, H.; Tsang, A.; van den Brink, J. M.; Atkins, A.; Aerts, A.; Shapiro, H.; Pangilinan, J.; Salamov, A.; Lou, Y.; Lindquist, E.; Lucas, S.; Grimwood, J.; Grigoriev, I. V.; Kubicek, C. P.; Martinez, D.; van Peij, N. N.; Roubos, J. A.; Nielsen, J.; Baker, S. E.; Genome Res. 2011, 21, 885.

17. Meyer, V.; Biotechnol. Adv. 2008, 26, 177.

18. Zheng, X.; Zheng, P.; Sun, J.; Kun, Z.; Ma, Y.; Fungal Biol. Biotechnol. 2018, 5, 2.

19. Song, L.; Ouedraogo, J.; Kolbusz, M.; Nguyen, T. T. M.; Tsang, A.; PLoS One 2018, 13, e0202868.

20. Henrikson, J. C.; Hoover, A. R.; Joyner, P.; Cichewicz, R. H.; Org. Biomol. Chem. 2009, 7, 435.

21. Fisch, K. M.; Gillaspy, A. F.; Gipson, M.; Henrikson, J. C.; Hoove, A. R.; Jackson, L.; Najar, F. Z.; Wägele, H.; Cichewicz, R. H.; J. Ind. Microbiol. Biotechnol. 2009, 36, 1199.

22. Parshikov, I. A.; Woodling, K. A.; Sutherland, J. B.; Appl. Microbiol. Biotechnol. 2015, 99, 6971.

23. Parshikov, I. A.; Woodling, K. A.; Sutherland, J. B.; Appl. Biochem. Biotechnol. 2015, 176, 903. 
24. Parshikov, I. A.; Sutherland, J. B.; Process Biochem. 2014, 49, 2086.

25. Bennett J. W.; Aspergillus: Molecular Biology and Genomics; Caister Academic Press: Poole, UK, 2010.

26. Schuster, E.; Dunn-Coleman, N.; Frisvad, J. C. P.; van Dijck, W. M.; Appl. Microbiol. Biotechnol. 2002, 59, 426.

27. Krijgsheld, P.; Altelaar, A. F. M.; Post, H.; Ringrose, J. H.; Müller, W. H.; Heck, A. J. R.; Wösten, H. A.; J. Proteome Res. 2012, 11, 2807.

28. Akiyama, K.; Teraguchi, S.; Hamasaki, Y.; Mori, M.; Tatsumi, K.; Ohnishi, K.; Hayashi, H.; J. Nat. Prod. 2003, 66, 136.

29. Fang, W.; Lin, X.; Wang, J.; Liu, Y.; Tao, H.; Zhou, X.; Molecules 2016, 21, 941.

30. Li, X. B.; Xie, F.; Liu, S. S.; Li, Y.; Zhou, J. C.; Liu, Y. Q.; Yuan, H. Q.; Lou, H. X.; Chem. Biodiversity 2013, 10, 1193.

31. Zhang, Y.; Li, X.-M.; Wang, B.-G.; J. Antibiot. 2007, 60, 204.

32. Song, Y. C.; Li, H.; Ye, Y. H.; Shan, C. Y.; Yang, Y. M.; Tan, R. X.; FEMS Microbiol. Lett. 2004, 241, 67.

33. Li, D.-H.; Han, T.; Guan, L.-P.; Bai, J.; Zhao, N.; Li, Z.-L.; Wu, X.; Hua, H.-M.; Nat. Prod. Res. 2016, 30, 1116.

34. Ghosal, S.; Biswas, K.; Chakrabarti, D. K.; J. Agric. Food Chem. 1979, 27, 1347.

35. Leutou, A. S.; Yun, K.; Son, B. W.; Arch. Pharm. Res. 2016, 39, 806.

36. Bouras, N.; Mathieu, F.; Coppel, Y.; Lebrihi, A.; Nat. Prod. Res. 2005, 19, 653 .

37. Tanaka, H.; Wang, P. L.; Namiki, M.; Agric. Biol. Chem. 1972, 36, 2511.

38. Bouras, N.; Mathieu, F.; Coppel, Y.; Strelkov, S. E.; Lebrihi, A.; J. Agric. Food Chem. 2007, 55, 8920.

39. Gorst-Allman, C. P.; Steyn, P. S. N.; J. Chem. Soc., Perkin Trans 1 1980, 2474.

40. Sakurai, M.; Kohno, J.; Yamamoto, K.; Okuda, T.; Nishio, M.; Kawano, K.; Ohnuki, T.; J. Antibiot. 2002, 55, 685.

41. Zhou, X.; Fang, W.; Tan, S.; Lin, X.; Xun, T.; Yang, B.; Liu, S.; Liu, Y.; Bioorg. Med. Chem. Lett. 2016, 26, 361.

42. Frisvad, J. C.; Petersen, L. M.; Lyhne, E. K.; Larsen, T. O.; PLoS One 2014, 9, e94857.

43. Happi, G. M.; Kouam, S. F.; Talontsi, F. M.; Nkenfou, C. N.; Longo, F.; Zühlke, S.; Douanla-Meli, C.; Spiteller, M.; Z. Naturforsch. B: J. Chem. Sci. 2015, 70, 625.

44. Zhang, Y.; Li, X. M.; Wang, C. Y.; Wang, B. G.; Chin. Chem. Lett. 2007, 18, 951.

45. Lu, S.; Tian, J.; Sun, W.; Meng, J.; Wang, X.; Fu, X.; Wang, A.; Lai, D.; Liu, Y.; Zhou, L.; Molecules 2014, 19, 7169.

46. Liu, D.; Li, X. M.; Meng, L.; Li, C. S.; Gao, S. S.; Shang, Z.; Proksch,P.; Huang, C. G.;Wang, B. G.;J.Nat.Prod. 2011, 74, 1787.

47. Zhang, Y.; Li, X. M.; Feng, Y.; Wang, B. G.; Nat. Prod. Res. 2010, 24, 1036.

48. Li, X. B.; Li, Y. L.; Zhou, J. C.; Yuan, H. Q.; Wang, X. N.; Lou, H. X.; J. Asian Nat. Prod. Res. 2015, 17, 182.
49. Talontsi, F. M.; Tatong, M. D. K.; Michel, D.; Dittrich, B.; Douanla-Meli, C.; Laatsch, H.; Tetrahedron 2013, 69, 7147.

50. Ui, H.; Shiomi, K.; Yamaguchi, Y.; Masuma, R.; Nagamitsu, T.; Takano, D.; Sunazuka, T.; Namikoshi, M.; Omura, S.; J. Antibiot. 2001, 54, 234.

51. Varoglu, M.; Crews, P.; J. Nat. Prod. 2000, 63, 41.

52. Barnes, C. L.; Steiner, J. R.; Torres, E.; Pacheco, R.; Marquez, H.; J. Peptide Protein Res. 1990, 36, 292.

53. Holm, D. K.; Petersen L. M.; Klitgaard, A.; Knudsen, P. B.; Jarczynska, Z. D.; Nielsen, K. F.; Gotfredsen, C. H.; Larsen, T. O.; Mortensen, U. H.; Chem. Biol. 2014, 21, 519.

54. Bugni, T. S.; Abbanat, D.; Bernan, V. S.; Maiese, W. M.; Greenstein, M.; Van Wagoner, R. M. V.; Ireland, C. M.; J. Org. Chem. 2000, 65, 7195.

55. Petersen, L. M.; Holm, D. K.; Knudsen, P. B.; Nielsen, K. F.; Gotfredsen, C. H.; Mortensen, U. H.; Larsen, T. O.; J. Antibiot. 2015, 68, 201.

56. Boecker, S.; Storm, D.; Meyer, V.; Richter, L.; Zobel, S.; Wanka, F.; Süßmuth, R.; Mühlenweg, A.; WO 2015/140315 A2 2015.

57. Uchoa, P. K. S.; Pimenta, A. T. A.; Braz-Filho, R.; Oliveira, M. C. F.; Saraiva, N. N.; Rodrigues, B. S. F.; Pfenning, L. H.; Abreu, L. M.; Wilke, D. V.; Florêncio, K. G. D.; Lima, M. A. S.; Nat. Prod. Res. 2017, 31, 2599.

58. Yoshizawa, T.; Tsuchiya, Y.; Morooka, N.; Sawada, Y.; Agric. Biol. Chem. 1975, 39, 1325.

59. Kim, S. Y.; Cho, A.; Kim, K. W.; Oh, S.; J. Plant Biol. 2004, $47,254$.

60. Koizumi, Y.; Nagai, K.; Gao, L.; Koyota, S.; Yamaguchi, T.; Natsui, M.; Imai, Y.; Hasumi, K.; Sugiyama, T.; Kuba, K.; Sci. Rep. 2018, 8, 5472.

61. Kim, K. W.; Sugawara, F.; Yoshida, S.; Murofushi, N.; Takahashi, N.; Curtis, R. W.; Biosci. Biotechnol. Biochem. 1993, $57,240$.

62. Kim, K. W.; Sugawara, F.; Uzawa, J.; Yoshida, S.; Murofushi, N.; Takahashi, N.; Curtis, R. W.; Kanai, M.; Tetrahedron Lett. 1991, 32, 6715.

63. Hagimori, K.; Fukuda, T.; Hasegawa, Y.; Omura, S.; Tomoda, H.; Biol. Pharm. Bull. 2007, 30, 1379.

64. Kobbe, B.; Cushman, M.; Wogan, G. N.; Demain, A. L.; Appl. Environ. Microbiol. 1977, 33, 996.

65. Anderegg, R. J.; Biemann, K.; Biichi, G.; Cushman, M.; J. Am. Chem. Soc. 1976, 98, 3365.

66. Mikušová, P.; Sulyok, M.; Santini, A.; Šrobárová, A.; Phytopathol. Mediterr. 2014, 53, 311.

67. Park, S. Y.; Oh, H. H.; Park, Y. L.; Yu, H. M.; Myung, D. S.; Cho, S. B.; Lee, W. S.; Park, D.; Joo, Y. E.; Int. J. Oncol. 2017, $51,959$.

68. Praveena, Y. S. N.; Padmini, P. P. C.; Int. J. Plant, Anim. Environ. Sci. 2011, 1, 8. 
69. Schlingmann, G.; Taniguchi, T.; He, H.; Bigelis, R.; Yang, H. Y.; Koehn, F. E.; Carter, G. T.; Berova, N.; J. Nat. Prod. 2007, $70,1180$.

70. Hiort, J.; Maksimenka, K.; Reichert, M.; Perovic-Ottstadt, S.; Lin, W. H.; Wray, V.; Steube, K.; Schaumann, K.; Weber, H.; Proksch, P.; Ebel, R.; Müller, W. E. G.; Bringmann, G.; J. Nat. Prod. 2004, 67, 1532.

71. Yamamoto, T.; Tsunematsu, Y.; Noguchi, H.; Hotta, K.; Watanabe, K.; Org. Lett. 2015, 17, 4992.

72. Riko, R.; Nakamura, H.; Shindo, K.; J. Antibiot. 2014, 67, 179.

73. Varoglu, M.; Corbett, T. H.; Valeriote, F. A.; Crews, P.; J. Org. Chem. 1997, 62, 7078.

74. Frisvad, J. C.; Lars, L. H.; Møller, L. L. H.; Larsen, T. O.; Kumar, R.; Arnau, J.; Appl. Microbiol. Biotechnol. 2018, 102, 9481.

75. Ding, L.; Li, T.; Liao, X.; He, S.; Xu, S.; J. Antibiot. 2018, 71, 902.

76. Isogai, A.; Washizu, M.; Kondo, K.; Murakoshi, S.; Suzuki, A.; Agric. Biol. Chem. 1984, 48, 2607.

77. Li, A.; Pfelzer, N.; Zuijderwijk, R.; Punt, P.; BMC Biotechnol. 2012, 12, 57.

78. Hossain, A. H.; Li, A.; Brickwedde, A.; Wilms, L.; Caspers, M.; Overkamp, K.; Punt, P. J.; Microb. Cell Fact. 2016, 15, 130.

79. Hasegawa, Y.; Fukuda, T.; Hagimori, K.; Tomoda, H.; Omura, S.; Chem. Pharm. Bull. 2007, 55, 1338.

80. Zhao, M.; Lu, X.; Zong, H.; Li, J.; Zhuge, B.; Biotechnol. Lett. 2018, 40, 455.

81. Priegnitz, B. E.; Brandt, U.; Pahirulzaman, K. A. K.; Dickschat, J. S.; Fleibner, A.; Eukaryotic Cell 2015, 14, 602.

82. Zhang, Y.; Li, X. M.; Proksch, P.; Wang, B. G.; Steroids 2007, 72,723 .

83. Liu, D.; Li, X. M.; Li, C. S.; Wang, B. G.; Helv. Chim. Acta 2013, 96, 1055.

84. Zabala, A. O.; Xu, W.; Chooi, Y. H.; Tang, Y.; Chem. Biol. 2012, 19, 1049.

85. Oveden, S. P. B.; Sberna, G.; Tait, R. M.; Wildman, H. G.; Patel, R.; Li, B.; Steffy, K.; Nguyen, N.; Meurer-Grimes, B. M.; J. Nat. Prod. 2004, 67, 2093.

86. Stothers, J. B.; Stoessl, A.; Can. J. Chem. 1988, 66, 2816.

87. Cutler, H. G.; Crumley, F. G.; Cox, R. H.; Hernandez, O.; Cole, R. J.; Dorner, J. W.; J. Agric. Food Chem. 1979, 27, 592.

88. Jefferson Jr., W. E.; Biochemistry 1967, 6, 3479.

89. Rao, K. C. S.; Divakar, S.; Rao, A. G. A.; Karanth, N. G.; Suneetha, W. J.; Krishnakantha, T. P.; Sattur, A. P.; Biotechnol. Lett. 2002, 24, 1967.

90. Rabache, M.; Neumann, J.; Lavollay, J.; Phytochemistry 1974, 13, 637.

91. Ray, A. C.; Eakin, R. E.; Appl. Microbiol. 1975, 30, 909.

92. Zhang, Y.; Wang, S.; Li, X. M.; Cui, C. M.; Feng, C.; Wang, B. G.; Lipids 2007, 42, 759.

93. Wu, Z. J.; Ouyang, M. A.; Su, R. K.; Guo, Y. X.; Chin. J. Chem. 2008, 26, 759 .
94. Yang, X. L.; Awakawa, T.; Wakimoto, T.; Abe, I.; ChemBioChem 2014, 15, 1578.

95. Fujimoto, Y.; Miyagawa, H.; Tsurushima, T.; Irie, H.; Okamura, K.; Ueno, T.; Biosci. Biotechnol. Biochem. 1993, 57, 1222.

96. Rao, K. C. S.; Divakar, S.; Srinivas, M.; Babu, K. N.; Karanth, N. G.; Sattur, A. P.; J. Antibiot. 2003, 56, 173.

97. Shen, L.; Ye, Y.-H.; Wang, X.-T.; Zhu, H.-L.; Xu, C.; Song, Y.-C.; Li, H.; Tan, R.-X.; Chem. - Eur. J. 2006, 12, 4393.

98. Siddiqui, B. S.; Ismail, F. A.; Gulzar, T.; Begum, S.; Nat. Prod. Res. 2003, 17, 355.

99. Almassi, F.; Ghisalberti, E. L.; Rowland, C. Y.; J. Nat. Prod. 1994, 57, 833 .

100. Inokoshi, J.; Shiomi, K.; Masuma, R.; Tanaka, H.; Yamada, H.; Omura, S.; J. Antibiot. 1999, 52, 1095.

101. Alvi, K. A.; Nair, B. G.; Rabenstein, J.; Davis, G.; Baker, D. D.; J. Antibiot. 2000, 53, 110.

102. Elfita; Muharni; Munawar; Aryani, S.; Indones. J. Chem. 2012, $12,195$.

103. Lee, M. Y.; Park, H. M.; Son, G. H.; Lee, C. H.; J. Microbiol. Biotechnol. 2013, 23, 932.

104. Nair, M. G.; Burke, B. A.; Phytochemistry 1988, 27, 3169.

105. Yuan, W.; Zhu, H.; Cheng, K.; Huang, Z.; Qin, Y.; Yang, J.; Zhu, P.; Nat. Prod. Res. 2006, 20, 573.

106. Rao, K. C. S.; Divakar, S.; Rao, A. G. A.; Karanth, N. G.; Sattur, A. P.; Appl. Microbiol. Biotechnol. 2002, 58, 539.

107. Borjesson, T. S.; Stollman, U. M.; Schnurer, J. L.; J. Agric. Food Chem. 1993, 41, 2104.

108. Iwamoto, T.; Hirota, A.; Shima, S.; Sakai, H.; Isogai, A.; Agric. Biol. Chem. 1985, 49, 3323.

109. Rao, K. C. S.; Divakar, S.; Babu, K. N.; Rao, A. G. A.; Karanth, N. G.; Sattur, A. P.; J. Antibiot. 2002, 55, 789.

110. Suresha, B. S.; Srinivasan, K.; Curr. Eye Res. 2013, 38, 1064.

111. Wani, M. A.; Sanjana, K.; Kumar, D. M.; Lal, D. K.; J. Basic Microbiol. 2010, 50, 110.

112. Fukuda, T.; Hasegawa, Y.; Hagimori, K.; Yamaguchi, Y.; Masuma, R.; Tomoda, H.; Omura, S.; J. Antibiot. 2006, 59, 480.

113. van Dijck, P. W. M.; Selten, G. C. M.; Hempenius, R. A.; Regul. Toxicol. Pharmacol. 2003, 38, 27.

114. Mogensen, J. M.; Frisvad, J. C.; Thrane, U.; Nielsen, K. F.; J. Agric. Food Chem. 2010, 58, 954.

115. Mansson, M.; Klejnstrup, M. L.; Phipps, R. K.; Nielsen, K. F.; Frisvad, J. C.; Gotfredsen, C. H.; Larsen, T. O.; J. Agric. Food Chem. 2010, 58, 949.

116. Frisvad, J. C.; Smedsgaard, J.; Samson. R. A.; Larsen, T. O.; Thrane, U.; J. Agric. Food Chem. 2007, 55, 9727.

117. Lewis, R. E.; Wiederhold, N. P.; Lionakis, M. S.; Prince, R. A.; Kontoyiannis, D. P.; J. Clin. Microbiol. 2005, 43, 6120.

118. Sorensen, L. M.; Lametsch, R.; Andersen, M. R.; Nielsen, P. V.; Frisvad, J. C.; BMC Microbiol. 2009, 9, 255.

119. Nielsen, K. F.; Mogensen, J. M.; Johansen, M.; Larsen, T. O.; Frisvad, J. C.; Anal. Bioanal. Chem. 2009, 395, 1225. 
120. Passamanni, F. R. F.; Hernandes, T.; Lopes, N. A.; Bastos, S. C.; Santiago, W. D.; Cardoso, M. G.; Batista, L. R.; J. Food Prot. 2014, 77, 1947.

121. Gerez, C. L.; Dallagnol, A.; Ponsone, L.; Chulze, S.; de Valdez, G. F.; Food Control 2014, 45, 115.

122. Fanelli, F.; Schmidt-Heydt, M.; Haidukowski, M.; Geisen, R.; Logrieco, A.; Mule, G.; World Mycotoxin J. 2012, 5, 169.

123. Gelderblom, W. C. A.; Jaskiewicz, K.; Marasas, W. F. O.; Thiel, P. G.; Horak, R. M.; Vleggaar, R.; Kriek, N. P. J.; Appl. Environ. Microbiol. 1988, 54, 1806.

124. Logrieco, A.; Feracane, R.; Haidukowsky, M.; Cozzi, G.; Visconti, A.; Ritieni, A.; Food Addit. Contam., Part A 2009, 26, 1495.

125. Susca, A.; Proctor, R. H.; Butchko, R. A. E.; Haidukowski, M.; Stea, G.; Logrieco, A.; Moretti, A.; Fungal Genet. Biol. 2014, 73,39 .

126. Selma, M. V.; Martinez-Culebras, P. V.; Elizaquivel, P.; Aznar, R.; Food Addit. Contam., Part A 2009, 26, 180.

127. Freire, L.; Guerreiro, T. M.; Pia, A. K. R.; Lima, E. O.; Oliveira, D. N.; Melo, C. F. O. R.; Catharino, R. R.; Sant'Ana, A. S.; Sci. Rep. 2018, 8, 14573.

128. Xiong, K.; Wang, X. L.; Zhi, H. W.; Suna, B. G.; Lia, X. T.; J. Sci. Food Agric. 2017, 97, 434.

129. Zhang, J.; Zhu, L.; Chen, H.; Li, M.; Zhu, X.; Gao, Q.; Wang, D.; Zhang, Y.; J. Agric. Food Chem. 2016, 64, 9680.

130. Serra, R.; Braga, A.; Venancio, A.; Res. Microbiol. 2005, 156, 515.

131. Borges, K. B.; Borges, W.S.; Durán-Patrón, R.;Pupo, M.T.; Bonato, P. S.; Collado, I. G.; Tetrahedron: Asymmetry 2009, 20, 385.

132. Bhatti, H. N.; Khera, R. A.; Steroids 2012, 77, 1267.

133. Cairns, T. C.; Nai, C.; Meyer, V.; Fungal Biol. Biotechnol. 2018, $5,13$.

134. Bhattacharyya, P. K.; Prema, B. R.; Kulkarni, B. D.; Pradhan, S. K.; Nature 1960, 187, 689.

135. Noma, Y.; Hashimoto, T.; Uehara, S.; Asakawa, Y.; Flavour Fragrance J. 2010, 25, 161.

136. Azizuddin, M. I.; Sherwani, S. K.; Chem. Nat. Prod. 2016, 52, 62.

137. Choudhary, M. I.; Musharraf, S. G.; Khan, M. T. H.; Abdelrahman, D.; Parvez, M.; Shaheen, F.; Rahman, A.; Helv. Chim. Acta 2003, 86, 3450.

138. Gliszczyńska, A.; Łysek, A.; Janeczko, T.; Świtalska, M.; Wietrzyk, J.; Wawrzeńczyk, C.; Bioorg. Med. Chem. 2011, 19 , 2464.

139. Iida, M.; Mikami, A.; Yamakawa, K.; Nishitani, K.; J. Ferment. Technol. 1988, 66, 51.

140. Cano, A.; Ramírez-Apan, M. T.; Delgado, G.; J. Braz. Chem. Soc. 2011, 22, 1177.

141. Goutric, S. C.; Feresin, G. E.; Tapia, A. A.; Rossomando, P. C.; Schmeda-Hirschimann, G.; Bustos, D. A.; World J. Microbiol. Biotechnol. 2004, 20, 281.
142. Aladessanmi, A.; Hoffmann, J. J.; Phytochemistry 1991, 30, 1847.

143. Hoffmann, J. J.; Punnapayak, H.; J. Nat. Prod. 1988, 51, 125.

144. Chou, B. H.; Yang, L. M.; Chang, S. F.; Hsu, F. L.; Lo, C. H.; Liaw, J. H.; Liu, P. C.; Lin, S. J.; J. Nat. Prod. 2008, 71, 602.

145. Chou, B. H.; Yang, L. M.; Chang, S. F.; Hsu, F. L.; Wang, L.; Liu, P. C.; Lin, S. J.; J. Nat. Prod. 2011, 74, 1379.

146. Chang, S. F.; Chou, B. H.; Yang, L. M.; Hsu, F. L.; Lin, W. K.; Ho, Y.; Lin, S. J.; Bioorg. Med. Chem. 2009, 17, 6348.

147. Esmaeili, A.; Rohany, S.; Safaiyan, S.; Zarei, S. A.; Czech J. Food Sci. 2011, 29, 610.

148. Mohammad, M. Y.; Shakya, A.; Al-Bakain, R.; Haroon, M. H.; Choudhary, M. I. C.; Bioorg. Chem. 2018, 80, 212.

149. Zhan, Y.; Liu, H.; Wu, Y.; Wei, P.; Chen, Z.; Williamson, J. S.; Appl. Microbiol. Biotechnol. 2015, 99, 3443.

150. Cano-Flores, A.; Delgado, G.; Chem. Biodiversity 2017, 14, e1700211.

151. Militsina, O. I.; Kovyljaeva, G. I.; Bakaleynik, G. A.; Strobykina, I. Y.; Kataev, V. E.; Alfonsov, V. A.; Musin, R. Z.; Beskrovny, D. V.; Litvinov, I. A.; Mendeleev Commun. 2005, $15,27$.

152. Orabi, K. Y.; Galal, A. M.; Ibrahim, A. R.; El-Feraly, F. S.; Khalifa, S. I.; El-Sohly, H. N.; Phytochemistry 1999, 51, 257.

153. Zhan, J.; Zhang, Y.; Guo, H.; Han, J.; Ning, L.; Guo, D.; J. Nat. Prod. 2002, 65, 1693.

154. Hashimoto, T.; Noma, Y.; Asakawaa, Y.; Heterocycles 2001, 54, 529.

155. Ata, A.; Betteridge, J.; Schaub, E.; Kozera, D. J.; Holloway, P.; Samerasekera, R.; Chem. Biodiversity 2009, 6, 1453.

156. Chen, Y.; Zhang, L.; Qin, B.; Zhang, X.; Jia, X.; Wang, X.; Jin, D.; You, S.; Nat. Prod. Res. 2014, 28, 454.

157. Inayama, S.; Gao, J. F.; Harimaya, K.; Hikichi, M.; Iitaka, Y.; Guo, Y. T.; Kawamata, T.; Chem. Pharm. Bull. 1985, 33, 2179.

158. Charney, W.; Herzoy, H. C.; Microbiological Transformation of Steroids; Academic Press: New York, USA, 1967, p. 48.

159. Areche, C.; San-Martín, A.; Rovirosa, J.; Soto-Delgado, J.; Contreras, R.; Phytochemistry 2009, 70, 1315.

160. Gerwick, W. H.; Fenical, W.; J. Org. Chem. 1981, 46, 22.

161. Wie, H. J.; Zhao, H. L.; Chang, J. H.; Kim, Y. S.; Hwang, K.; Ji, G. E.; J. Agric. Food Chem. 2007, 55, 8908.

162. Sanchez, J. F.; Somoza, A. D.; Keller, N. P.; Wang, C. C.; Nat. Prod. Rep. 2012, 29, 351.

163. Boecker, S.; Gratz, S.; Kerwat, D.; Adam, L.; Schirmer, D.; Richter, L.; Shutze, T.; Petras, D.; Sussmuth, R. D.; Meyer, V.; Fungal Biol. Biotechnol. 2018, 5, 4.

164. Niu, J.; Arentshorst, M.; Nair, P. D. S.; Dai, Z.; Baker, S. E.; Frisvad, J. C.; Nielsen, K. F.; Punt, P. J.; Ram, A. F. J.; G3: Genes, Genomes, Genet. 2016, 6, 193.

165. Hautbergue, T.; Jamin, E. L.; Debrauwer, L.; Puel, O.; Oswald, I. P.; Nat. Prod. Rep. 2018, 35, 147. 
166. Tawfike, A. F.; Tate, R.; Abbott, G.; Young, L.; Viegelmann, C.; Schumacher, M.; Diederich, M.; Edrada-Ebel, R.; Chem. Biodiversity 2017, 14, e1700040.

167. Lee, E.; Lee, S.; Jang, E. S.; Shin, H. W.; Moon, B. S.; Lee, C. H.; Molecules 2016, 21, 773.

168. Cichewicz, R. H.; Nat. Prod. Rep. 2010, 27, 11.

169. Ebrahim, W.; El-Neketi, M.; Lewald, L. I.; Orfali, R. S.; Lin, W.; Rehberg, N.; Kalscheuer, R.; Daletos, G.; Proksch, P.; J. Nat. Prod. 2016, 79, 914.
170. Vadlapudi, V.; Borah, N.; Yellusani, K. R.; Gade, S.; Reddy, P.; Rajamanikyam, M.; Vempati, L. N. S.; Gubbala, S. P.; Chopra, P.; Upadhyayula, S. M.; Amanchy, R.; Sci. Rep. 2017, 7, 7325.

Submitted: January 28, 2019 Published online: May 7, 2019 